\title{
Monitoring Australian Monsoon variability over the past four glacial cycles
}

\author{
Pei Renjie ${ }^{1,}{ }^{*}$, Kuhnt Wolfgang ${ }^{1}$, Holbourn Ann ${ }^{1}$, Hingst Johanna ${ }^{1,2}$, Koppe Matthias ${ }^{1}$, Schultz Jan ${ }^{1}$, \\ Kopetz Peer ${ }^{1}$, Zhang Peng ${ }^{3}$, Andersen Nils ${ }^{4}$
}

${ }^{1}$ Institute for Geosciences, Kiel University, Ludewig-Meyn Str. 10-14, 24118 Kiel, Germany

2 MARUM, University of Bremen University, Leobener Str. 8, 28359 Bremen, Germany

3 State Key Laboratory of Continental Dynamics, Department of Geology, Northwest University, Xi'an

710069, China

${ }^{4}$ Leibniz Laboratory for Radiometric Dating and Stable Isotope Research, Kiel University, Max-Eyth-Str. 11-13, 24118 Kiel, Germany

* Corresponding author : Renjie Pei, email address : $\underline{\text { Renjie.Pei@ifg.uni-kiel.de }}$

Wolfgang.kuhnt@ifg.uni-kiel.de ; Ann.Holbourn@ifg.uni-kiel.de ; ihingst@marum.de ; stu121922@mail.uni-kiel.de ; nandersen@leibniz.uni-kiel.de

\begin{abstract}
:
We analyse changes in terrigenous sedimentation along the northwestern Australian margin to monitor the latitudinal migration of the Intertropical Convergence Zone (ITCZ) and the shifting boundaries of climatic belts during the last four glacial cycles. We integrate high-resolution X-ray fluorescence (XRF) scanning elemental records from Core SO257-18548 and International Ocean Discovery Program Site U1482, situated southwest of the Scott Plateau at the southern edge of the present-day monsoonal belt, and from Core SO257-18571, located within the dust-cyclone belt offshore Northwest Cape south of the Exmouth Plateau. The chronology of these sediment successions is based on $14 \mathrm{C}$ dating over the last glacial termination and on correlation of the benthic oxygen isotope record to the LR04 stack (Lisiecki and Raymo, 200) and Antarctic ice core chronology. Our XRF derived records of riverine terrigenous run-off and aeolian dust input reveal rapid intensification of monsoonal precipitation and reduction of atmospheric dust during the Younger Dryas and early Holocene as well as during the terminal phase of other major deglaciations. Short-lived monsoonal maxima in the early Holocene ( $10 \mathrm{ka})$, MIS $5 \mathrm{e}(\sim 130 \mathrm{ka})$, MIS 7 $(\sim 200, \sim 220$ and $\sim 240 \mathrm{ka})$, and MIS $9(\sim 280, \sim 305$ and $\sim 330 \mathrm{ka})$ coincide with maxima in atmospheric carbon dioxide and methane concentrations. Monsoon intensification occurs during maxima in Southern Hemisphere spring (September) insolation, when intense heat low pressure cells over the Pilbara region trigger the southward shift of the ITCZ. Within the dust-cyclone belt, riverine sediment discharge was restricted to intervals of high atmospheric $\mathrm{CO} 2$ concentrations, when sea surface temperature thresholds promoted cyclone formation in the tropical Indian Ocean. Northwestern Australia remained dry and arid during MIS 5a-d, when the ITCZ was locked in a more northerly position and temperature thresholds were not attained.
\end{abstract}




\section{Highlights}

- Rapid intensification of Australian monsoon at end of glacial terminations I to IV Monsoon intensification coincided with atmospheric $\mathrm{CO}_{2}$ increase - Austral spring insolation drove southward shift of ITCZ and monsoon intensification - Formation of regional heat lows instrumental for monsoonal hydroclimate Aeolian dust dominant during glacials and MIS $5 \mathrm{a}-\mathrm{d}$ south of $20^{\circ} \mathrm{S}$.

Keywords: ITCZ, Glacial terminations, Dust, Terrigenous discharge, Oxygen isotopes, X-Ray fluorescence 


\section{Introduction}

The climate and hydrography of the eastern Indian Ocean (Timor Sea) and northwestern Australia are strongly influenced by seasonal changes in wind direction associated with the southward migration of the Intertropical Convergence Zone (ITCZ) during austral summer. During December-February, NW winds predominate and rainfall increases over Indonesia and northern Australia (Australian summer monsoon), whereas dry SE Trade Winds prevail during austral winter (June-November). Today, a striking feature of northwestern Australian climate is the formation of low pressure cells between September and November, which precede the monsoon season by up to three months. The development of these heat lows is a critical factor in the formation of the Australian summer monsoon circulation, as they trigger strong westerly winds (Suppiah, 1992). These heat lows form over the desert region. under clear skies at high insolation in areas were surface albedo is high. The intensity and geogra ${ }_{1}$ hic extent of these heat lows are highly sensitive to changes in insolation, thus responding to both ext rna insolation and internal greenhouse forcing.

On longer timescales, variations in monsoonal rainfali 、 $\mathrm{re} r$ lated to changes in precessional summer insolation, sea level fluctuations and atmospheric $r \Gamma_{2}$ concentrations (e.g., Wyrwoll et al., 2007; Griffiths et al., 2009; DiNezio and Tierney, 2013; Kuhr it al , 2015). There is also a broad consensus that the meridional position of the ITCZ, which contrr $s \mathrm{~s}$ t e lavitudinal extent of monsoonal rainfall, is strongly dependent on the interhemispheric temperature grau. 'nt (e.g., Schneider et al., 2014; Mohtadi et al., 2016). Climate models predict drier subtropics in the Su 'thern Hemisphere during interstadials due to a northward shift of the ITCZ during Dansgaa $d \mathrm{O}$ sschger (D/O) warming events in the Northern Hemisphere and a southward displacem $\mathrm{tt}$ or the ITCZ during Northern Hemisphere cooling (Claussen et al., 2003; Broccoli et al., 2006; Chiang ` al., 2008). These changes likely result from shifts in the atmospheric heat exchange betwee. the uropics and mid latitudes and attendant variations in Trade Winds (e.g., Broccoli et al., 2006). Ho veve , the response of the Australian Monsoon to high-latitude temperature fluctuations on orbital, suborbita ${ }^{\prime}$ and millennial timescales is still poorly understood due to the scarcity of continuous high-resolution precipitation and runoff records from the Australian continent.

The sedimentary archives along the northwestern Australian margin, south of the fulcrum of the ITCZ's seesaw, are ideally situated to test the validity of these model predictions. The seasonal southward and northward migrations of the ITCZ and associated austral monsoonal rain belt directly influence sedimentation patterns in the Timor Sea. Austral summer monsoon rainfall during southward shifts of the ITCZ increases river discharge, leading to enhanced deposition of terrigenous sediment along the continental margin. In contrast, when the ITCZ is locked into a more northerly position, the austral summer monsoon weakens, vast areas of northern Australia dry out and intensified Trade Winds in austral winter carry increased amounts of dust from the arid zones of central and northwestern Australia into the SE Timor Sea. Sedimentation patterns along the northwestern Australian margin are, thus, directly related 
to the latitudinal migration of the monsoon rain belt, making this area ideally suited to test model predictions of Southern (Northern) Hemisphere temperature forcing of the Australian Monsoon.

Today, the delivery of dust from the Australian continent towards the eastern Indian Ocean is controlled by the seasonal change in wind direction associated with the southward migration of the ITCZ during austral summer. During December-February, NW winds predominate and rainfall increases over Indonesia and northern Australia (Australian summer monsoon), whereas dry SE Trade Winds, which transport dust particles originating from the central Australian deserts, prevail during austral winter-spring in June-October. Pioneering sedimentologic studies of sediment cores offshore northwestern Australia suggested that changes in grain size offer a valuable proxy to estimate the amount of wind-blown desert dust in the terrigenous fraction of hemipelagic sediments in this area (Heirtzler 1974; Mc Tainsh, 1989; Hesse and McTainsh, 2003). Furthermore, these studies provided evidence $t_{1}{ }^{\prime t}$ provenance and transport mechanisms (wind direction and intensity) were highly variable over or ital imescales. For example, grain size analysis in Core SO14-08-05 (16 $\left.21^{\prime} \mathrm{S}, 118^{\circ} 23^{\prime} \mathrm{E}\right)$ on the Ro rley errace between the Scott Plateau and Exmouth Plateau indicated that the dust flux consisted of coars * grains during the Last Glacial Maximum (LGM) in comparison to the early Holocene (Turne, et $\varepsilon_{1 . .}, 2006$ ). This record also exhibits maxima in dust flux at $\sim 8,14,30$ and $150 \mathrm{ka}$ (MIS 6), assn riaced with Southern Hemisphere cooler climate phases (Hesse and McTainsh, 2003, Hesse et al., 2004; Tu ne; et al, 2006). Spikes of aeolian quartz grains in Lake Carpentaria also coincide with Northern ${ }_{1}$ en 'sph re warm phases/Southern Hemisphere cool phases (De Deckker, 2001), in particular dust peaks sentered at 24.0, 25.4 and $29.5 \mathrm{ka}$ and two peaks within broader maxima at $\sim 34.6$ and $\sim 38.6 \mathrm{ka}$ al associated with D/O-Events 3, 4, 7 and 8 .

Previous studies of Australian sedin e' ta $y$ archives also suggested that the northern Australian monsoonal rainbelt expanded and intens i ied curing suborbital cooling and drying phases in the Northern Hemisphere. The Lynch's Crater sedin. 'nt records provided evidence for intensified monsoonal rainfall over northern Australia during Hei. rich 1-3 stadials (HS 1-3) and the Holocene 8.2 ka cold event (Muller et al., 2008). By contrast, North arn $\mathrm{I}$ 'emisphere tropical and equatorial rainfall was weakest during these cold phases. In records from the SE Asian Maritime Continent, such as northern Borneo (Partin et al., 2007), the Sulu Sea (Rosenthal et al, 2003) and Sulawesi (Schröder et al., 2016, 2018), the weakest tropical convection and driest conditions characterize the early deglaciation HS 1 (18-15 ka). While there is evidence of a suborbital seesaw in monsoonal rainfall intensity for the LGM, deglaciation and early Holocene, the long-term orbital and suborbital evolution of the Australian Monsoon remains enigmatic, mainly due to the scarcity of continuous high-resolution records extending beyond the last glacial cycle. The only high-resolution monsoonal records that cover this extended time interval are located further to the northeast and are strongly influenced by upwelling-related productivity changes of the Indonesian Throughflow, driven by monsoonal winds during glacial low stands (Holbourn et al., 2005; Kawamura et al., 2006; Sarnthein et al., 2011). IMAGES Core MD00-2361, located at the margin of the Exmouth Plateau near the North West Cape, tracked glacial-interglacial changes in riverine and dust supply over the last $550 \mathrm{kyr}$, but the relatively low mean sedimentation rates of $2.5 \mathrm{~cm} / \mathrm{kyr}$ with substantially lower rates 
during glacials did not allow full reconstruction of millennial scale monsoonal variability at this location (Stuut et al., 2014).

Here, we compare X-ray fluorescence (XRF) core scanner-derived elemental records in two extended sediment successions retrieved at the southern edge of the present-day monsoonal belt southwest of the Scott Plateau and within the dust-cyclone belt offshore Northwest Cape to monitor monsoonal runoff and dust fluxes on millennial timescales over the last four glacial cycles. Our main objectives are to reconstruct the variability of the tropical convection along the southernmost displacement of the ITCZ during austral summer in relation to changes in high-latitude climate, sea level and atmospheric greenhouse gas concentration in order to monitor changes in the latitudinal temperature gradient and the intensity of the Walker circulation.

\section{Regional setting}

\subsection{Climate archives along the northwestern Austra: an margin}

Deep-water sediments along the northwestern Australı $\urcorner \mathrm{m}$, rgin consist of autochthonous biogenic carbonate with a small biosiliceous component and fine-grained terrigenous input from the Australian continent, which bypasses the broad shelf in su. ne' sion. One of the most prominent features is a distinct NE-SW decrease in late Pleistocene-Ho' oce ne sudimentation rates (Keep et al., 2018; Kuhnt et al., 2018). This trend has been explained by a comb. ation of southward decreasing subsidence and accommodation space with increasing distance $\left.\iota_{1}\right\urcorner \mathrm{m}$ the northern margin of the Australian plate (Keep et al., 2018) and decreasing discharge of riveri.ie se siment southward of the Australian monsoonal rain belt (Gingele and De Deckker 2004; De Dec' ker c: al., 2014; Kuhnt et al., 2015). R/V Sonne Cruise 257 (WACHEIO) retrieved a suite of sedimı $n t$ cores along transects seaward of the northwestern Australian shelf to better understand the sedir. $n$ nt 1 ansport offshore and the dynamics of depositional systems and to reconstruct long-term climate e olut on from these high-resolution sediment archives. Preliminary evaluation indicates that sedime, tation rates exceeded $5 \mathrm{~cm} / \mathrm{kyr}$ during the late Pleistocene to Holocene in the northeastern part of the margin, whereas the Rowley Terrace between the Scott Plateau and Exmouth Plateau displays intermediate sedimentation rates ranging between 2.8 and $5.0 \mathrm{~cm} / \mathrm{kyr}$ (Figure 1). South of the Exmouth Peninsula, sedimentation rates are generally below $2 \mathrm{~cm} / \mathrm{kyr}$ and increase basinwards, which highlights the important role of slope-parallel sediment advection in this area (Figure 1).

\subsection{Factors influencing fluvial sediment discharge}

The amount and chemical composition of sediment discharge by rivers from the Australian continent are influenced by multiple factors including the catchment-basin size, the relief and associated stream gradient, the bedrock lithology, the tectonic setting, and ultimately the amount and seasonality of rainfall. The succession of climate belts in northwestern Australia from (1) monsoonal tropical humid in the north through (2) tropical semi-arid with sporadic rainfall from cyclones during the summer monsoon 
season, (3) arid and (4) temperate with dominant rain in austral winter in the south (Figure 1) is reflected in the composition of the river sediment loads and marine surface sediments along the adjacent margin.

However, clay mineral distribution offshore northwestern Australia does not exhibit a simple latitudinal distribution pattern, with kaolinite (Al-Fe rich) dominating in warm and humid latitudes and illite/chlorite (K-rich) in cold and arid regions (Gingele et al., 2001). High illite and chlorite concentrations also occur near the equator and high kaolinite concentrations were observed south of $35^{\circ}$, which has been attributed to specific local sources (Gingele et al. 2001; Gingele and DeDeckker, 2004). These authors found illite concentrations of $25-36 \%$ in rivers discharging from the monsoonal climate zone in northern Australia with particularly high illite concentrations (50 and $54 \%$ of the clay mineral content) in sediments from the Ashburton River and adjacent Mangrove Creek, which discharge from the semi-arid Pilbara mountain range. These results are consistent with potassium (K) concentrations in che, ${ }^{~}{ }^{-}$cal analyses of sediments from these rivers and adjacent offshore regions (Figure 2). A possible e $\mathrm{n}$.lan tion for the high illite content in clay mineral assemblages and the associated high $\mathrm{K}$ conce ntral ons in the elemental composition of the fine grained sediment from the semi-arid zone is the intense c nsion in elevated parts of the catchment during catastrophic rainfall events and the rapid anc tire $\mathrm{t}$ sediment transport in sporadic flash floods.

\section{Material and methods}

\subsection{Core locations and sediment recovery}

Piston Core SO257-18548 (15³.59 '`, ' 20¹8.846’ E, $1608.2 \mathrm{~m}$ water depth, $11.2 \mathrm{~m}$ core length) and International Ocean Discovery Progr am ' 'ODP) Site U1482 (15 $3.32^{\prime} \mathrm{S}, 120^{\circ} 26.10^{\prime} \mathrm{E}, 1466 \mathrm{~m}$ water depth), located close to the modern so thern limit of the seasonal (austral summer) displacement of the ITCZ, are influenced by the monsconal lischarge from the nearby Fitzroy River (Figure 2). Core SO25718548 is located $\sim 7 \mathrm{~nm}$ west of ${ } \mathrm{OL}^{D}$ Site U1482 at the western edge of an elevated plateau that forms the northeastern part of the Rowley Terrace between the Scott Plateau and Exmouth Plateau. Core SO25718548 was retrieved during a sıe survey in the vicinity of IODP Site U1482. The main objective of coring at this location was to recover the late Pleistocene to Recent sedimentary record, which is missing at Site U1482, as a local sediment gravity flow eroded sediments younger than MIS 9. Recovered sediments consist of homogenous mottled olive greenish gray to dark gray clay-rich calcareous ooze (Kuhnt et al., 2018; Rosenthal et al., 2018; Supplementary Figure S1).

Gravity Core SO257-18571 (22 ${ }^{\circ}$ 6,666'S, 113 $29,688^{\prime} \mathrm{N}, 1052 \mathrm{~m}$ water depth, $20.1 \mathrm{~m}$ core length) was retrieved offshore the North West Cape Peninsula south of the Exmouth Plateau (Figure 2). The core is located within the "dust-cyclone" climate belt at the northern end of the arid climatic zone in Western Australia and is only marginally affected by the austral summer monsoon rain belt. This area receives mainly water and sediment from the Ashburton, Fortescue, Gascoyne and De Grey Rivers, which sporadically have high discharges following torrential rainfall after the landfall of tropical cyclones (Figure 
2C). Core SO257-18571 is located at the western edge of an E-W orientated ridge at a position, where 8 khz seismic reflectors indicated locally higher sedimentation rates. Recovered sediments consist of clayrich nannoplankton ooze with distinct intercalations of dark reddish brown, clay-rich intervals and light olive gray calcareous ooze (Kuhnt et al., 2018; Supplementary Figures S2 and S3).

\subsection{Sampling and processing}

The working halves of Cores SO257-18548 and -18571 were initially sampled at $10 \mathrm{~cm}$ intervals ( $1 \mathrm{~cm}$-thick half slices of $11 \mathrm{~cm}$ diameter cores). Additional samples were taken over Termination I (6 samples from Core SO257-18548 between 94.5 and $204.5 \mathrm{~cm}$ depth) and Termination II (10 samples from Core SO257-18548 between 456.5 and $576.5 \mathrm{~cm}$ depth) to refine the age model. Four holes were cored at Site U1482 during IODP Expedition 363 (Rosenthal et al., 2017, 2018). The vorking halves from the composite sediment succession (shipboard splice) between 24.76 and $3(22$, leters composite depth (mcd) were sampled at $20 \mathrm{~cm}$ intervals ( $2 \mathrm{~cm}$-thick half slices of $\sim 7 \mathrm{~cm}$ dia nete $\cdot$ cores). The sediment succession from Core SO257-18548 and nearby Site U1482 were combined. bu ed on correlation of the highresolution XRF scanner elemental records (Supplementary Fig, res ',4 and S5). The tie point, corresponding to an age of $\sim 324 \mathrm{ka}$, is located at $10.84 \mathrm{~m}$ in Core SU257-18548 and at $24.97 \mathrm{mcd}$ in Site U1482. All samples were oven dried at $40^{\circ} \mathrm{C}$ and weigh $z_{2}$, ri , r to washing over a $63 \mu \mathrm{m}$ sieve. Residues were oven dried at $40^{\circ} \mathrm{C}$ on filter paper, then weig led and vieved into the fractions $>315,315-250,250-150$ and $150-63 \mu \mathrm{m}$.

\subsection{Stable isotope analysis}

Stable oxygen isotopes of the ef-hent.ic foraminifer Cibicidoides wuellerstofi were measured in 132 samples from Core SO257-18548, ¿` samples from Site U1482 and 150 samples from Core SO25718571. In each sample, 3-6 well-pı served specimens of $C$. wuellerstofi were picked from the fraction $>315 \mu \mathrm{m}$ and/or 315-2:0 $0 \mathrm{n}$. Selected well-preserved specimens were crushed into large fragments, agitated with ethanoı ${ }^{\mathrm{C}}$ or 2-3 $\mathrm{s}$ in an ultrasonic bath, decanted and dried at $40{ }^{\circ} \mathrm{C}$ prior to analysis with a Thermo Finnigan MAT 253 mass spectrometer at the Leibniz Laboratory for Radiometric Dating and Isotope Research, Kiel University, Kiel. The mass spectrometer is coupled to a Kiel-Carbo IV device for automated $\mathrm{CO}_{2}$ preparation from carbonate samples. Sample reaction was induced by individual acid addition $\left(99 \% \mathrm{H}_{3} \mathrm{PO}_{4}\right.$ at $\left.75{ }^{\circ} \mathrm{C}\right)$ under vacuum. The evolved carbon dioxide was analysed eight times for each individual sample. As documented by the performance of international [NBS19: $+1.95 \%$ VPDB $\left({ }^{13} \mathrm{C}\right),-2.20 \%$ VPDB $\left({ }^{18} \mathrm{O}\right)$; IAEA-603: $+2.46 \%$ VPDB $\left({ }^{13} \mathrm{C}\right),-2.37 \%$ VPDB $\left.\left({ }^{18} \mathrm{O}\right)\right]$ and laboratoryinternal carbonate standards [Hela1: $+0.91 \%$ VPDB $\left({ }^{13} \mathrm{C}\right),+2.48 \% \operatorname{VPDB}\left({ }^{18} \mathrm{O}\right)$; HB1: $-12.10 \%$ VPDB $\left({ }^{13} \mathrm{C}\right),-18.10 \% \operatorname{VPDB}\left({ }^{18} \mathrm{O}\right)$; SHK: $\left.+1.74 \% \operatorname{VPDB}\left({ }^{13} \mathrm{C}\right),-4.85 \% \operatorname{VPDB}\left({ }^{18} \mathrm{O}\right)\right]$, analytical precision of stable isotope analysis is better than $\pm 0.08 \%$ for $\delta^{18} \mathrm{O}$ and better than $\pm 0.05 \%$ for $\delta^{13} \mathrm{C}$. Values are calibrated relative to Vienna Pee Dee Belemnite. 


\subsection{Age models}

Between 0 and $\sim 21 \mathrm{ka}$, the age models of Cores SO257-18548 and -18571 are based on ${ }^{14} \mathrm{C}$ dates obtained from the surface-dwelling planktonic foraminifer Globigerinoides ruber (white). Between 600 and 800 specimens of the planktic foraminifer $G$. ruber $>250 \mu \mathrm{m}$ were picked for AMS dating in order to reach a sample weight of $12 \mathrm{mg}$. In both cores, we selected samples at depths close to the transition between the Bølling-Allerød and the Younger Dryas and close to the center of the LGM. Samples were measured at the Leibniz Laboratory for Radiometric Dating and Isotope Research, Kiel University, Kiel. Conventional radiocarbon ages were converted into calendar ages using Calib 7.1 (Stuiver et al. 2019). We applied a marine reservoir age of 510 years for the sample at a depth of $70 \mathrm{~cm}$ in Core $18548(>13 \mathrm{ka}), 200$ years for the sample at a depth of $140 \mathrm{~cm}$ in Core 18571 (>10 ka) and 1600 years for the samples at a depth of 100

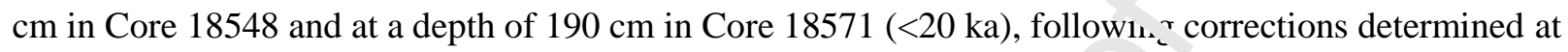
the nearby Core MD01-2378 (Sarnthein et al., 2011).

For the interval older than $21 \mathrm{ka}$, we derived age models for Cor ; SO257-18548 and -18571 and for Site U1482 (between 24.76 and $30.22 \mathrm{mcd}$ ) by correlating the $\mathrm{b}$ nthic foraminiferal $\delta^{18} \mathrm{O}$ records to the reference benthic isotope stack LR04 (Lisiecki and Raymo, 26, 5), , sing linear interpolation between tie points (Linage) in AnalySeries 2.08 (Paillard et al., 1996)

\subsection{XRF scanner derived elemental composition}

Bulk-chemical composition of the sedimen 'res was determined using a $2^{\text {nd }}$ generation Avaatech XRF core scanner at the Institute of Geosciences, Kiel University. Before measurement, the sediment surface was smoothed and covered with a 4.) in thick Prolene ${ }^{\circledR}$ Thin-Film foil to minimize surface irregularities and to avoid direct contact 'etwı en the sediment and the detector. Measurements were carried out on the archive halves at $1 \mathrm{c}_{1}$ intervals over a $1.2 \mathrm{~cm}^{2}$ area with a down core slit size of $10 \mathrm{~mm}$, using generator settings of $10,30 \mathrm{a} \cdot d 51 \mathrm{kV}$ tube voltages. We performed measurements for 15 seconds with $200 \mu \mathrm{A}$ without filter for $\mathrm{t}$ e $1 \mathrm{c} \mathrm{kV}$ runs and for 10 seconds with $1000 \mu \mathrm{A}$ using a $\mathrm{Pb}$ and $\mathrm{Cu}$-filter for the 30 and $50 \mathrm{kV}$ runs, respectiv ly. The spectra were transferred into elemental area counts using the software bAxil Batch by Brightspec NV and are reported as area counts per second. Results are reported in logarithms of elemental ratios, which provide the most easily interpretable signals of relative changes in chemical composition downcore and minimize the risk of measurement artefacts from variable signal intensities and matrix effects (Weltje and Tjallingii, 2008).

We used the sum of the spectral area counts of the elements aluminium $(\mathrm{Al})$, silicon ( $\mathrm{Si}$ ), potassium $(\mathrm{K})$, iron $(\mathrm{Fe})$, titanium $(\mathrm{Ti})$ as proxies for the terrigenous derived sediment component (abbreviated as “Terr") mainly originating from riverine transport from the Australian continent. We normalized these elements against calcium $(\mathrm{Ca})$, derived from the biogenic carbonate of marine plankton. An alternative normalization was performed against barium $(\mathrm{Ba})$, which is related to particulate organic matter and/or the precipitation of barite by marine bacteria and is, thus, independent of carbonate production and dissolution. The $\log (\mathrm{Terr} / \mathrm{Ba})$ curve exhibit similar trends in all cores as $\log (\mathrm{Terr} / \mathrm{Ca})$, 
suggesting that the variability of these records is mainly driven by increasing or decreasing terrigenous flux (Supplementary Figure S6). Core scanner measurements of the split core sediment surface commonly underestimate concentrations of the light elements $\mathrm{Al}$ and $\mathrm{Si}$, due to the influence of pore water in unconsolidated sediment (Tjallingii et al., 2007). However, replicate XRF scanner measurements of compressed dry powder from the same core interval show that pore water bias affects only the uppermost $\sim 100 \mathrm{~cm}$ of our cores. The $\log (\mathrm{Al} / \mathrm{Ca})$ and $\log (\mathrm{Si} / \mathrm{Ca})$ curves in this interval become noisier in both cores, but do not substantially differ from curves of the heavier elements $(\log (\mathrm{K} / \mathrm{Ca}), \log (\mathrm{Ti} / \mathrm{Ca})$, and $\log (\mathrm{Fe} / \mathrm{Ca}))$ over the last glacial termination and Holocene (Supplementary Figure S7A and B).

Differences in the abundance of zirconium ( $\mathrm{Zr}$ ) and light elements ( $\mathrm{Al}, \mathrm{K}$ or rubidium $(\mathrm{Rb})$ ) reflect the grain size and transport pathway of terrigenous particles, since $\mathrm{K}, \mathrm{Al}$ and $\mathrm{Rb}$ are preferentially

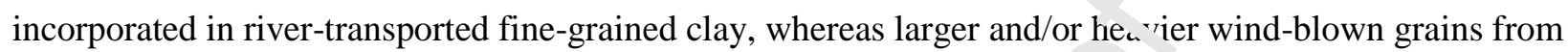
the Australian desert have relatively high $\mathrm{Zr}$ values. Zirconium is the m: in cr mponent of the heavy mineral zircon, which is subject to sorting and preferential settling c sse 1 ) river mouths and on the continental shelf, and thus mainly characterizes wind transported $a_{n}{ }^{-t}$ at distal locations. In particular, $\mathrm{Zr} / \mathrm{Rb}$ in sediment has been shown to reflect the initial grain $\mathrm{si}_{\llcorner} \cdot \mathrm{di}$;ribution (coarser sediment $\mathrm{Zr}$ enriched, finer sediments clay mineral bound $\mathrm{Rb}$-enriched if wind-olown sediments, due to the immobility of the two elements during post depositiona' p. ore sses (Liu, 2002).

\subsection{Calibration of XRF scanner data by melt XRF u. alysis of discrete samples}

To calibrate the XRF scanner data, 11 homogen. ${ }^{2}$ ed and discrete samples of the terrigenous sediment component from Core SO257-18571 and 9 sar ip es from Core SO257-18548 were analysed using quantitative XRF analysis of fused beats For ciscrete sample measurements, all samples were decarbonatized by adding $10 \% \mathrm{HCl} \mathrm{un}_{\mathbf{1}} .1$ the reaction stopped. The suspension was neutralized after centrifugation for $10 \mathrm{~min}$ at $3000 \mathrm{k}$ volu tions/min, decanted and refilled with deionized water. This neutralization was repeated six ime: The neutralized suspension was wet sieved over a $63 \mu \mathrm{m}$ sieve and the fine fraction $(<63 \mu \mathrm{m})$ colle ${ }^{\prime}$ ed and filled into beakers. After 5 weeks, the supernatant was carefully pumped out. After drying at $50^{\circ} \mathrm{C}$, aliquots of each sample were used to produce fused beads and pressed pellets (Garbe-Schönberg and Müller, 2014). Fused beats were produced by mixing the sample material with lithium-tetraborate and heated to $\sim 1050^{\circ} \mathrm{C}$. Major and trace elements were determined on the fused lithium-tetraborate glass disks with a X-ray fluorescence spectrometer (XRF - Panalytical MagixPro) at Hamburg University using the software of Vogel and Kuipers (1987). Accuracy was controlled by analyses of several international standards. The precision of the instrument is 1-2 \% for major elements and 5-20\% for trace elements depending on the concentration. Loss on ignition (LOI) was determined gravimetrically after heating the samples to $1050{ }^{\circ} \mathrm{C}$ for 3 hours (Lechler and Desilets, 1987). Pressed pellets were produced by grinding down the dried material first with a mortar and afterwards with a Pulverisette 7 premium line from Fritsch, pressed into pellets and measured with the second generation Avaatech XRF core scanner at the Institute of Geosciences, Kiel University. Analytical results of 
quantitative fused beats XRF and corresponding XRF scanner area counts for Core SO257-18548 are provided in Supplementary Table S1A and B and for Core SO257-18571 in Supplementary Table S2A and B. Linear regression plots are shown in Supplementary Figure S8.

\subsection{Elemental signatures of Western Australian river sediments}

To determine the provenance of the terrigenous component of marine sediments, samples from Core SO257-18548 (core-top samples) and Core SO257-18571 (core depth $113.5 \mathrm{~cm}$ ) were compared with finegrained $(<63 \mu \mathrm{m})$ sediments from the main rivers in northwestern Australia. The chemical composition of marine and river sediments was analyzed by melt XRF analysis of discrete samples. Aliquots of the same samples were additionally analyzed in discrete pellets with the XRF scanner at Kiel University. After decarbonatization, the samples were pulverized in an agate mortar and presse ${ }^{-1}$ into pellets with a Pulverisette 7 premium line from Fritsch, then analyzed with the XRF c, re s anner at Kiel University.

\section{Results}

\subsection{Chronology and sedimentation rates}

Between 0 and $\sim 21 \mathrm{ka}$, the age models of Core $\left.S^{-1}\right)^{5} 7-18548$ and -18571 are based on ${ }^{14} \mathrm{C}$ AMS dates (Table 1). To derive age models prior to 21 'a 1 Cures SO257-18548 and -18571 and at Site U1482, we selected consistent tie points between the benthı foraminiferal $\delta^{18} \mathrm{O}$ curves and the reference benthic isotope stack LR04 (Lisiecki and Raymo, 2005) 'Table 2, Figures 3-4). For the interval from 24.76 to $30.22 \mathrm{mcd}$ at Site U1482, shipboard biostrat g ap uic datums provided additional age constraints between 0.29 to $0.44 \mathrm{Ma}$ (Rosenthal et al., 2018) · Figu.e 3).

Sedimentation rates $(\mathrm{SR})$ in $\mathrm{C}_{0^{\circ}} \cdot \mathrm{SO} 257-18571$ exhibit a distinct glacial-interglacial variability (Figure 4). Mean SR range betwee. $8.6 \mathrm{~cm} / \mathrm{kyr}$ during MIS 5e and $11.5 \mathrm{~cm} / \mathrm{kyr}$ during the Holocene, whereas mean SR are substanti. lly li wer during glacial periods, varying between $3.7 \mathrm{~cm} / \mathrm{kyr}$ during MIS 6 and $4.5 \mathrm{~cm} / \mathrm{kyr}$ during the LGM. Sedimentation rates during MIS 3, 4 and 5a-d also remain low, as during the LGM and MIS 6. By contrast, sedimentation rates for Core SO257-18548 and at Site U1482 show more consistent trends of 2.5 to $5.5 \mathrm{~cm} / \mathrm{kyr}$ without major glacial and interglacial differences (Figure 3).

We additionally tested the robustness of the age models by correlating our oxygen isotope records to the Antarctic $\delta \mathrm{D}$ derived temperature record (Bazin et al., 2013). Within the range of error in our intermediate resolution ( 2-4 kyr) isotope records, the onset of glacial terminations occurs simultaneously, whereas the end of glacial terminations (temperature maximum) is 2 to $5 \mathrm{kyr}$ later in the marine record (Supplementary Figure S9).

\subsection{Composition and provenance of terrigenous sediment discharge}

Comparison of the terrigenous elemental composition of Core SO257-18548 with that of the riverine sediment discharge from the Kimberley coast, which is the closest sediment source on the 
Australian continent shows a high degree of affinity (Figure 2, Table 3). In particular, the terrigenous component of Core SO257-18548 is very close to that of the fine-grained clay-fraction dominating the King Sound sediment near Derby, where the Fitzroy River enters into the shelf sea. The coarser grained, silt-dominated sediment, sampled upstream of the Fitzroy River exhibits higher Si percentages, which is mainly due to the higher quartz content of the silt fraction. The elevated $\mathrm{K}$ content is typical for this area, which agrees with clay mineral analyses showing higher percentages of the K-rich clay mineral illite (Gingele and DeDeckker, 2004). In the vicinity of the Northwest Cape Peninsula, the sediment loads of the Ashburton, Fortescue and Gascoyne Rivers exhibit similar elemental compositions with higher Fe concentrations, which are closely reflected in the composition of the Holocene terrigenous sediment fraction in Core SO257-18571, located offshore from these rivers (Figure 2, Table 3).

\subsection{Variations in riverine terrigenous sediment input}

$\log (\mathrm{Terr} / \mathrm{Ca})$ is used to estimate the contribution of terrigenous sec mer $t$ discharge normalized against the marine biogenic carbonate flux, which is considered to be relat 1 ly constant offshore northwestern Australia (Kuhnt et al., 2015). In Cores SO257-18571 and -18 ' 1 a ..d at Site U1482, Log (Terr/Ca) shows glacial-interglacial variability that is generally coherent $w_{\ldots .}^{i \ldots}$ tne $\delta^{18} \mathrm{O}$ records (Supplementary Figure S10A). In Core SO257-18548, glacial-interglacial $\left.(\sim 10) \mathrm{k}^{\prime}, r\right)$ ioherence is $>0.8$ with an out-of-phase relationship (highest $\log \left(\mathrm{Terr} / \mathrm{Ca}\right.$ ) coincide with ' $\mathrm{ow}$ ' st $\delta^{\circ} \mathrm{O}$ ), while coherence at the precessional band (23 kyr) is highest (0.83). However, there is a distinc. mismatch between $\delta^{18} \mathrm{O}$ and terrigenous runoff during MIS 5a and 5c, when terrigenous runoff $\_$mains comparable to glacial levels in Cores SO25718548 and -18571. In Core SO257-18571, cur er nce is highest ( 0.85) at the glacial-interglacial scale, whereas it is lower ( 0.76) at the preces onal oand (Supplementary Figure S10B).

During glacial stages, mean ${ }^{\top} \mathrm{o}_{5}$ 'Terr/Ca) is distinctly lower in Core SO257-18571 than in Core SO257-18548, with a minimum vaı 0 o -1.5 during MIS 5d to MIS 2 and higher values of -1.2 to -1.3 during MIS 8 and MIS 6, respe tive $y$. In Core SO257-18548, mean $\log (\mathrm{Terr} / \mathrm{Ca})$ is -1.1 for MIS $5 \mathrm{~d}$ and MIS 2 and -0.9 for MIS 8 and $\mathrm{N}_{\imath}$ S 6 . Maximum values are reached in both cores as distinct sharp peaks at the end of glacial terminations or at the beginning of interglacials: at $\sim 10 \mathrm{ka}$ (end of Termination I/early Holocene), $\sim 130 \mathrm{ka}$ (end of Termination II/early MIS 5e), 200, 220 and $\sim 240 \mathrm{ka}$ (end of Termination III/ early MIS7 and precessional insolation maxima within MIS 7) and at $\sim 280, \sim 305$ and $\sim 330 \mathrm{ka}$ (end of Termination IV/early MIS 9 and precessional insolation maxima within MIS 9 and MIS 8). Maxima are comparable (between -0.2 and -0.5) in both cores, although minima are distinctly lower in Core SO25718571, suggesting a higher amplitude change of sediment discharge from the semi-arid zone in northwestern Australia than from catchments within the monsoonal rainbelt. In addition, the deglacial onset of enhanced discharge from the semi-arid zone was more rapid, in particular during Termination II, when $\log (\mathrm{Terr} / \mathrm{Ca})$ in Core SO257-18548 already exhibits an increasing trend in the late MIS 6, whereas Core SO257-18571 $\log (\mathrm{Terr} / \mathrm{Ca})$ shows an abrupt change point at the onset of the glacial termination. The 
runoff pattern across MIS 11 differs markedly from the later interglacial trends: the $\log (\mathrm{Terr} / \mathrm{Ca})$ curve is almost symmetrical without a distinct peak in the early part of the interglacial.

Accumulation rates of the terrigenous component in Core SO257-18571 are lower than $\sim 1$ $\mathrm{g} /\left(\mathrm{cm}^{2} \mathrm{kyr}^{1}\right)$ during glacial MIS 2-4, 6 and 8 and reach maxima of $>4 \mathrm{~g} /\left(\mathrm{cm}^{2} \mathrm{kyr}^{1}\right)$ during interglacial MIS 9, 7, 5e and 1 (Supplementary Figure S11). The increases in accumulation rates occur abruptly close to the end of glacial terminations in parallel to increases in carbonate accumulation associated with increasing biogenic carbonate production (Supplementary Figures S11 and S13). The deglacial increase in terrigenous accumulation rates in Core SO257-18548 is less dramatic and restricted to MIS 7 and MIS 1, while the accumulation rates of both the carbonate and terrigenous components remain low during MIS 5e (Supplementary Figures S11 and S12). Carbonate accumulation rates are helow $\sim 1 \mathrm{~g} /\left(\mathrm{cm}^{2} \mathrm{kyr}^{1}\right)$ during MIS $5 \mathrm{e}$, which is lower than during the preceding glacial stage. During MIS 5d to MIS 5a, carbonate accumulation rates increase continuously, then fluctuate at $\sim 2 \mathrm{~g} /\left(\mathrm{cm}^{2} \mathrm{ky}{ }_{1}^{1}\right) \mathrm{do}$ ing MIS 4 to 2 , which is $\sim 0.5$ $\mathrm{g} /\left(\mathrm{cm}^{2} \mathrm{kyr}^{1}\right)$ lower than average Holocene values. In contrast, chang $\mathrm{s}$ in : edimentation rates between glacial and interglacial stages at Site SO257-18548 are relativelv lo :" or even absent in the case of MIS 5, although the sediment composition changes significantly from . arb' nate dominated during glacials to terrigenous clay dominated during interglacials.

\subsection{Variations in dust input}

$\log (\mathrm{Zr} / \mathrm{Rb})$ in Core SO257-18571 exhibits distinct glacial/interglacial cyclicity, in contrast to the record from Core SO257-18548 and Site $\mathrm{U}_{1}{ }^{\circledR} 2$, which shows relatively low values with only subtle shifts between glacial and interglacial perious $\mathrm{T}$ lis distinct cyclicity in Core SO257-18571 parallels the oxygen isotope trend and is in antiphase ' 7 tha of $\log (\mathrm{Terr} / \mathrm{Ca})$. The abrupt decreases in dust input and increases in riverine terrigenous inpr oi clay minerals occur almost simultaneously during Terminations I, II and III. During interglacial perioc $\sim$ I $) g(\mathrm{Zr} / \mathrm{Rb})$ remains low, ranging between 0.28 and 0.5 (20 point smoothed data), whereas mean raluc $;$ are high (0.6 to 1.0) during glacial stages. Parallel to the marked decrease in $\log (\mathrm{Terr} / \mathrm{Ca})$ at the nd of MIS $5 \mathrm{e}, \log (\mathrm{Zr} / \mathrm{Rb})$ displays the largest increase within the record and exhibits a distinct maximum during MIS 5d. Between this maximum and the next pronounced peak during the LGM, three smaller maxima with an amplitude $\leq 0.2$ occur. These peaks approximately coincide with the cold MIS 5b and MIS 4 intervals and the central part of MIS 3 (Figure 5). Between the LGM and the Holocene, $\log (\mathrm{Zr} / \mathrm{Rb})$ decreases markedly once again. This decline is not continuous, but is interrupted by small plateaus at $\sim 25$ to $23 \mathrm{ka}, \sim 21$ to $17.5 \mathrm{ka}$, and $\sim 14$ to $10 \mathrm{ka}$. During the Holocene, $\log (\mathrm{Zr} / \mathrm{Rb})$ ranges between 0.27 and 0.43 with a standard deviation of 0.03 .

\section{Discussion}

\subsection{Reconstruction of monsoonal discharge}


Terrigenous flux reconstructions are based on XRF scanner derived concentrations of $\mathrm{Al}, \mathrm{Si}, \mathrm{K}, \mathrm{Fe}$ and Ti. These elements are commonly used to estimate the proportion of terrigenous (lithogenic) content in marine sediments, however, there are various caveats associated with each element. The concentration of $\mathrm{Al}$ is preferentially used to estimate the total lithogenic content of sediments because its concentration is very consistent in the continental lithosphere (Turekian and Wedepohl, 1961; Wedepohl, 1971; Taylor and McLennan, 1985). Silicon is present in all aluminosilicates and also occurs as quartz $\left(\mathrm{SiO}_{2}\right)$, which is the main component in the silt fraction of sediments and sedimentary rocks (Calvert and Pedersen, 2007). Core scanner measurements of the split-core sediment surface commonly underestimate concentrations of the light elements $\mathrm{Al}$ and $\mathrm{Si}$, due to the influence of pore water in unconsolidated sediment (Tjallingii et al., 2007). However, replicate XRF scanner measurements of compressed dry powder from the same core interval show that pore water bias affects only the uppermost $\sim 100 \mathrm{~cm}$ of ou ${ }^{-}$ores and does not substantially affect the shape of the $\log (\mathrm{Terr} / \mathrm{Ca})$ curve over the last gla 'ial ' 'ermination and Holocene (Supplementary Figure S6).

Potassium predominantly occurs as a component of the cla, mineral illite in fine-grained riverine runoff. Its concentration is reliably estimated by the XRF scan. 'ng echnique (Tjallingii et al., 2007) and it has been previously used to monitor monsoonal riverine rinnelf across the last glacial termination (Kuhnt et al., 2015). Iron and $\mathrm{Ti}$ were used to evaluate the changi ig $n n_{\lambda}$ t of fine-grained terrigenous siliciclastic

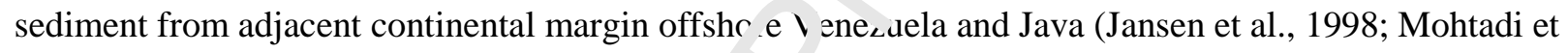
al., 2011; Haug et al., 2001), which was driven by vu iations in rainfall and runoff from the watersheds of local rivers. However, Ti usually exhibits fairly : 'w counts, when analysed with the XRF scanner, and the Fe content may be partly biased by the form.it on of authigenic iron/manganese crusts or pyrite (Calvert and Pederson 2007; Poulton and Raiswe' , 2022).

Using the sum of terrigenous $e_{\text {. }}$ ments instead of individual elements reduces the noise in XRF scanner data, since this produces $h_{i}$ her counts and reduces the effects of possible biases in single element counts. Here, we used the logar thm : ratio of the sum of the terrigenous elements $\mathrm{Al}, \mathrm{Si}, \mathrm{K}, \mathrm{Fe}$, and $\mathrm{Ti}$ to $\mathrm{Ca}(\log (\mathrm{Terr} / \mathrm{Ca}))$. This approa ' ' is commonly used in carbonate-rich pelagic environments, where carbonate dissolution plays no major role (Kuhnt et al., 2015). The carbonate concentrations vary between 54 and $80.5 \%$ in Core SO257-18548 and between 50 and $86 \%$ in Core SO257-18571. We assume that the variability in $\log (\mathrm{Terr} / \mathrm{Ca})$ in these two cores is mainly driven by changes in terrigenous input. Calcium is relatively rare in terrigenous sediments and in marine deep-water environments mainly derived from biogenic carbonate. To further test this hypothesis, we normalized against Ba (Supplementary Figure S6), which is related to particulate organic matter flux and/or the precipitation of barite by marine bacteria (Gonzalez-Munoz et al, 2012; Griffith et al, 2012) and, thus, has no direct relation to carbonate flux. In previous records from the northwestern Australian margin, $\mathrm{CaCO}_{3}$ and organic productivity indicators such as total organic carbon (TOC) and chlorins did not show any positive correlation (Holbourn et al., 2005). Thus, we conclude that the consistent behaviour of terrigenous elements normalized against $\mathrm{Ca}$ or $\mathrm{Ba}$ 
indicates that fluctuations in the Ca-normalized terrigenous elemental curves are caused by fluctuations in terrigenous input rather than changing marine carbonate production/dissolution.

\subsection{Monsoonal response to changes in atmospheric greenhouse gas concentrations and high-latitude} temperature fluctuations

Model predictions of changes in the latitudinal extent of the ITCZ's seasonal swing and the development of an interhemispheric seesaw during the last glacial cycle are contradictory and not fully supported by climate proxy data, which are still scarce for the Southern Hemisphere (Denton et al., 2010; Shakun et al., 2012; De Deckker et al., 2012; Kuhnt et al., 2015). In particular, increasing greenhouse gas concentrations during HS 1 (Lüthi et al., 2008; Shakun et al., 2012) should have resulted in tropical expansion (Seidel et al., 2008) at the end of the LGM. Expansion and contra tion of the monsoonal rain belt triggered by greenhouse gas concentrations is supported by a comp " "iso' . of high-resolution Northern and Southern Hemisphere speleothem records over the last three mil enn $\mathrm{l}$, which indicates coeval intensification/poleward shift and weakening/equatorward shift of 1 . nnsoonal rain belts on suborbital timescales in both hemispheres (Denniston et al., 2016). Howt or, ' ubstantial regional cooling associated with widespread drying in the subtropics and tropics in the Northern Hemisphere during HS 1 and preceding Heinrich stadials was attributed to a southwa d. nif. of the ITCZ and associated monsoonal rain belt (Claussen et al., 2003; Chiang and Bitz, 2005, CI iang et al., 2003, 2008; Broccoli et al., 2006; Muller et al., 2008, 2012; Bayon et al., 2017; Strikis et al., _ 18; Lauterbach et al., 2020). By contrast, a recent compilation of model ensembles for different for -ings demonstrated the importance of additional forcings on the variability of the ITCZ, including dis.ar va ıce of the global ocean circulation by North Atlantic hosing and LGM boundary conditions ( 1 twou d et al., 2020). While insolation differences between hemispheres and atmospheric $p \mathrm{CO}_{2}$ art :mportant, they may not alone force a mean shift of the tropical rainbelt. Moreover, precipitation $\mathrm{p}_{1}$ `xy rata compilations demonstrated that the height of HS 1 coincided with a latitudinally widespread Irou $_{i}$ ht, which also affected the Southern Hemisphere (Stager et al., 2011). According to these authors, the - idespread geographic range of aridification during HS 1 suggests a severe weakening of the tropical rainfall systems probably as a response to global sea surface cooling.

Our high-resolution runoff records from Core SO257-18548 and Site U1482, and from Core SO257-18571 also exhibit no distinct increase in riverine discharge in the early part of Termination I, suggesting that northwestern Australia remained largely arid during HS 1. A massive and rapid increase in riverine discharge started only at $\sim 13 \mathrm{ka}$ at these sites following the Antarctic Cold Reversal ( $15-13 \mathrm{ka})$. This is consistent with records within the core area of the Australian monsoonal rain belt further to the northeast, where terrigenous runoff also did not significantly increase prior to $13 \mathrm{ka}$ (Kuhnt et al., 2015). These generally dry conditions were only locally interspersed by transient rainfall episodes during HS 1 , HS 2, and HS 4, as indicated by composite stalagmite $\delta^{13} \mathrm{C}$ records from caves in the Kimberleys in northwestern Australia (Denniston et al., 2017). On orbital timescales, it is remarkable that the ITCZ appears to have consistently remained in a more northerly position during MIS $5 \mathrm{~b}$ and $5 \mathrm{~d}$ and associated 
stadials and that northwestern Australia remained consistently dry and dusty. By contrast, eastern Australia experienced increased precipitation linked to southward expansion of the ITCZ (Bayon et al., 2017). Recent modelling studies underline the role of longitudinally variable responses of the ITCZ to different climate forcings (Atwood et al., 2020) which could explain different responses to Northern Hemisphere cooling in eastern (Bayon et al., 2017; Muller et al., 2008) and western Australia.

Although our records do not resolve short-term local precipitation changes, they may provide a better estimate of time- and regional-averaged long-term precipitation and runoff trends on millennial timescales. The dampened response to changes in the interhemispheric temperature gradient in these "smooth" records supports the hypothesis of global subtropical megadroughts during intervals of globally cool climate and low atmospheric $p \mathrm{CO}_{2}$. Major wet periods in northwestern Australia are restricted to warmer-than-present climate intervals in the early Holocene ( 10 ka), earlv ${ }^{\top}{ }^{\top} \mathrm{IS}$ 5e ( 130 ka), MIS 7 $(\sim 200, \sim 220$ and $\sim 240 \mathrm{ka})$, and MIS $9(\sim 280, \sim 305$ and $\sim 330 \mathrm{ka})$, when non oonal rainfall also increased in many Northern Hemisphere monsoonal regions (Liu et al., 2014; Then s et al., 2016; Kathayat et al., 2016). In particular, the intense monsoonal peaks centered at $\sim 10$. 130, 240 and $\sim 330 \mathrm{ka}$, which follow Southern Hemisphere high-latitude temperature maxima at the nd 'f glacial terminations (Figure 6), suggest an enhanced regional response of the Australian M^nsoon, ariven through internal feedbacks. The general coherence between the intensity of the Australi $\mathrm{n}$ : $\mathrm{N}^{\prime}$ soon and global $p \mathrm{CO}_{2}$ and climate trends is also reflected in the high coherence and consister an phave behavior of benthic $\delta^{18} \mathrm{O}$ and monsoonal discharge in our records (Supplementary Figure S1し, Model experiments with warm Pliocene boundary

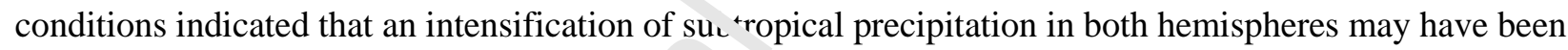
driven by reduced meridional sea-surface te. ar er uture gradients in a warmer world (Burls and Fedorov, 2017) and was decoupled from shifts of + e li $\mathrm{i} Z$ on millennial timescales (Sniderman et al., 2019).

\subsection{Temporal changes in the exten tf the northwestern Australian arid zone}

Today, estimates of ter gen us dust accumulation off northwestern Australia range between 1 and $5 \mathrm{~g} /\left(\mathrm{m}^{2} \mathrm{yr}^{1}\right.$ ) (Jickells et al., 2005, which represents $\sim 2-5 \%$ of the total sediment mass accumulation or $>10 \%$ of the terrigenous component at marine sites within the dust belt with typical deglacial sedimentation rates of $\sim 5 \mathrm{~cm} / \mathrm{kyr}^{1}$ (Figure 1A)(Kuhnt et al., 2018). The proportion of dust-blown sediment considerably decreases towards the northeast, where sedimentation rates increase and dust accumulation decreases, implying that a substantial proportion of the $\mathrm{Zr}$, Ti and Fe content is of aeolian origin only at the southerly location of Core SO257-18571. The aeolian terrigenous material that reaches distal marine locations is usually deposited during extreme dust outbreaks (Rea, 1994). The occurrence of discrete $\mathrm{Zr}-$, Ti- and Fe-enriched layers in the glacial intervals of Core SO257-18571 may, thus, represent a record of major dust storms (Rea, 1994; Hanebuth and Henrich, 2009).

Riverine transported fine-grained terrigenous discharge and aeolian dust input in Core SO25718571 exhibit a clear antiphase relationship with no recognizable phase lags, suggesting coeval and abrupt changes towards wetter climate and increased fluvial discharge during glacial terminations and rapid re- 
aridification at the end of the unusually warm isotope stages MIS 9, 7 and 5e. Increased dust transport to the eastern Indian Ocean implies a reduced vegetation cover during periods of increased seasonal aridity in the source area, following changes in preferential wind direction and/or strengthening of winds. The rapid intensification of monsoonal rainfall and re-aridification at the onset and end of the warmest intervals with highest atmospheric greenhouse gas levels suggest that these rapid transitions were defined by transgressing boundary condition thresholds. However, there are striking differences in the sedimentation processes and the climate of the catchment area at the locations of Core SO257-18548 and Site U1482 within the monsoonal belt and of the more southwestern Core SO257-18571 within the dust-cyclone belt. Precipitation in the arid zone almost exclusively occurs during the landfall of major tropical cyclones, which form in the tropical Indian Ocean during the monsoonal season, when SST thresholds of $26-27^{\circ} \mathrm{C}$ are reached (Tory and Dare, 2015). Increased cyclone activity during monsou $n$ intensification is also reflected by massive increases in sedimentation rates during the warm si 'ges MIS 1, MIS 5e and the warm parts of MIS 7 and MIS 9 in Core SO257-18571 (Figure 4), whereas sedı nentation rates in Core SO25718548, which is dominated by seasonal monsoonal discharge, remai ${ }^{\wedge}$ more consistent (Figure 3). Southern Hemisphere subtropical sea surface temperatures may have pla ${ }^{\prime} \cdot{ }^{\prime}$ : major role in setting these boundary conditions. However, boundary conditions remained below the threshold necessary for the formation of tropical cyclones during the slightly cooler interglacial $4: 5$, and MIS 5c, which remained dry and dusty within the dust-cyclone belt (Figure 5).

\subsection{Monsoon forcing mechanisms}

The intensity, seasonality and latitucir al extent of monsoonal rainfall during the summer season depend on the seasonal displacement of ${ }^{+} \mathrm{e}$ li $\mathrm{CZ}$, which is influenced by insolation differences between the Northern and Southern Hemisphert. (Broccoli et al., 2006) and is also highly sensitive to greenhouse gas forcing (Cai et al., 2012). How ver, the response of the ITCZ to interhemispheric insolation and temperature differences appear: regi nally variable and dependent on additional local forcings (Atwood at al., 2020). Sedimentary success $n$ ns at the more northeasterly situated Site U1483 and Core MD01-2378 in the Timor Sea display a similar monsoonal runoff pattern as Core SO257-18548 and Site U1482 (Zhang et al., 2020). The runoff record at these locations exhibits in-phase variability with Northern Hemisphere monsoonal precipitation records on the precession band, which was interpreted as an expansion (contraction) of the latitudinal extent of the ITCZ during Northern Hemisphere insolation maxima (minima) (Zhang et al. 2020).

Our comparison of two sedimentary succession providing a transect across the southernmost limit of the Australian Monsoon shows that regional factors additionally play a crucial role in controlling the seasonal position of the ITCZ and intensity of monsoonal rainfall over northwestern Australia. In particular, the seasonal and interannual heat and air pressure variability over the more elevated Pilbara area acts as a main driver of monsoonal hydroclimate. In austral winter and spring, subtropical high-pressure systems are positioned over the central part of the Australian continent forcing dry easterly or 
southeasterly Trade Winds over the Pilbara region, thus maintaining intensely arid conditions (Charles et al., 2015; Sudmeyer, 2016). The seasonal southward movement of subtropical high-pressure systems in September results in the dominance of tropical heat lows over the Pilbara region during the extremely hot and dry spring and the summer wet season. The position of this heat low is related to the location of the Pilbara region between the relatively cooler marine area to the north and latitudinally decreasing solar insolation to the south. In recent decades, an expansion of the Southern Hemisphere Hadley Cell in association with global warming caused a northward shift of frontal systems at the northern end of the Hadley Cell during austral winter and intensification of winter aridity in the Pilbara region (Lu et al., 2007; Risbey et al., 2009; Frederiksen et al., 2013).

The most intense phase of the heat low, which occurs in spring ard early summer (SeptemberNovember), precedes the monsoon season and is not associated with local rai-fall (Charles et al., 2009). However, the intensity and position of the heat low have significant rep "cus, ions in "pulling" the monsoonal rain belt southwards, resulting in a coupled relationship l etwt en the strength of the monsoonal circulation and associated heavy rainfall with the intensity of the ht. tow (Suppiah, 1992). Important controlling factors on the variability in the intensity and positic of he heat low on multidecadal, millennial and orbital timescales include (1) the precession ${ }^{n 1}$ variability of spring (September-October)

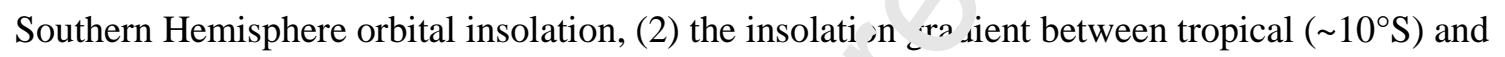
subtropical $\left(\sim 30^{\circ} \mathrm{S}\right)$ insolation, which prevents th he $\mathrm{t}$ lov from moving southwards into areas of lower insolation when the gradient is steep and, (3) the $\mathrm{co}_{1}$-entration of atmospheric greenhouse gases, which contributes to the intensity of the heat low. Durn.? the last $450 \mathrm{kyr}$, maxima in these three factors occurred at $\sim 10, \sim 130, \sim 200, \sim 220, \sim 240, \sim 280, \sim 305$ a id $\sim 330 \mathrm{ka}$, when terrigenous flux from monsoonal runoff strongly increased or was at a maximum, mosiy close to the end of glacial terminations (Figures 6-7, Supplementary Figure S14).

During MIS 12 to 10, inson tior forcing over the Pilbara region was minimal and the insolation gradient between 10 and $30^{\circ} \mathrm{S} \mathrm{r}$ ma1 ed elevated, which resulted in a more gradual monsoonal onset with muted response to precessional $i$ rcing. This weaker and more gradual monsoon intensification at the end of glacial Termination V (MIS 11) may have been additionally affected by pronounced vegetation changes leading to lower austral spring albedo of the Pilbara mountains. Palynological data indicate a major change in northwestern Australian subtropical vegetation patterns and hydroclimate associated with the onset of intense aridification at $\sim 350$ ka during MIS 10 (Kershaw et al., 2003; Kawamura et al., 2006). This major, long-term change in Australian subtropical hydroclimate was associated with the Mid-Brunhes Climate Transition (Jansen et al., 1986; Barth et al., 2018), which occurred during an interval of low precessional insolation forcing between 430 and $350 \mathrm{ka}$ and was followed by an increase in the amplitude of the Earth's 100 kyr glacial-interglacial climate cycles.

Atmospheric methane concentration records in ice cores exhibit extreme spikes associated with glacial terminations, which closely match the main atmospheric $\mathrm{CO}_{2}$ peaks (Figure 6) (Loulergue et al., 2008). The origin of these short-lived millennial scale methane maxima in the atmosphere has been 
intensely discussed with high-latitude permafrost and peatlands and low-latitude monsoonal wetlands being the prime candidates as the main sources for the rapid atmospheric methane increase (Chappellaz et al., 1990; Guo et al., 2011; Thirumalai et al., 2020) that may have contributed to the interhemispheric synchronization of glacial terminations. Low-latitude hydroclimate and vegetation changes, thus, may have contributed to intensified greenhouse gas release in subtropical regions and development of global methane and $p \mathrm{CO}_{2}$ maxima during glacial terminations (Rhodes et al., 2015; Bock et al., 2017).

\section{Conclusions}

XRF scanner derived increases in terrigenous discharge indicate rapid intensification of the Australian Monsoon at the end of glacial terminations with short-lived peaks in the early Holocene $(\sim 10$ ka), MIS 5e ( 130 ka), MIS 7 ( 200, 220 and $\sim 240 \mathrm{ka})$, and MIS $9(\sim 280, \cdot 205$ and $\sim 330 \mathrm{ka})$. The correlation of monsoonal precipitation and runoff proxies and Antarctic emr erature, $\mathrm{CO}_{2}$ and $\mathrm{CH}_{4}$ concentrations during the last five glacial terminations suggests that he i tensification of heat low pressure cells over northwestern Australia at the end of glacial terminations . 'as mainly driven by rapidly increasing atmospheric greenhouse gas concentrations in conju. ctir a with a low insolation gradient between Southern Hemisphere tropics and subtropics and ricing and/or high Southern Hemisphere springearly summer insolation. The formation of intense heat 'o, nv sssure cells in the Pilbara region of northwestern Australia in late September may hav p p lyec a crucial role in driving the ITCZ southwards and triggering intensified monsoonal rainfall on orb al timescales, when Southern Hemisphere insolation was at a maximum. Changes in riverine terrigen. 's sediment supply at the onset of MIS 11 were more gradual and do not indicate an abrupt chang $\mathrm{f}$. $\mathrm{ol} \mathrm{u}$ arid to monsoonal wet conditions, suggesting that an extended period of low variability in pre essı nal spring insolation and expanded vegetation cover over northwestern Australia weakened the $\mathrm{h}$ it low pressure cell over the Pilbara mountains. Southward swings of the ITCZ amplified and deglacia.' mo isoonal onsets intensified with aridification of northwestern Australia $\sim 350$ kyr ago.

\section{Acknowledgements}

This research used data and samples provided by the International Ocean Discovery Program (IODP). We are grateful to the Sonne 257 and IODP Expedition 363 shipboard scientific parties for all their efforts. Renjie Pei gratefully acknowledges financial support from the State Scholarship Fund of China Scholarship Council. We thank Matthias Hüls for AMS ${ }^{14} \mathrm{C}$ analyses at the Leibniz Laboratory for Radiometric Dating and Isotope Research, Kiel and Stefan Jung for fused beat XRF measurements at the Institute of Mineralogy and Petrography in Hamburg. We are grateful for constructive comments from two anonymous reviewers, which helped us to improve the manuscript. This study was funded by the German Federal Ministry of Education and Research (Grant SO-257, WACHEIO, 03G0257A).

\section{Conflict of interest}


The authors declare that they have no conflict of interest.

Supplementary data

Supplementary materials

\section{References}

Atwood, A.R., Donohoe, A., Battisti, D.S., Liu, X., Pausata, F.S.R., 2020. Robust Longitudinally Variable Responses of the ITCZ to a Myriad of Climate Forcings. Geophys. Res. Lett. 47. doi:10.1029/2020GL088833

Barth, A.M., Clark, P.U., Bill, N.S., He, F. and Pisias, N.G., 2018. Climate evolution across the Mid-Brunhes Transition. Climate of the Past, 14(12). doi:10.5194/cp-14-2071-2018

Bayon, G., De Deckker, P., Magee, J.W., Germain, Y., Bermell, S., Tachika ‥ n., Norman, M.D., 2017. Extensive wet episodes in Late Glacial Australia resulting from high-latitude orclıys. Sci. Rep. 7, 1-7. doi:10.1038/srep44054

Bazin, L., Landais, A., Lemieux-Dudon, B., Kele, H.T.M., Vere „, D., Parrenin, F., Martinerie, P., Ritz, C., Capron, E., Lipenkov, V. and Loutre, M.F., 2013. An optimized m'lti-pruxy, multi-site Antarctic ice and gas orbital chronology (AICC2012): 120-800 ka. Climate u, th Past, European Geosciences Union (EGU), 2013, 9 (4), pp. 1715-1731. doi:10.5194/cp-9-1715-2013

Bock, M., Schmitt, J., Beck, J., Seth, B., Chappe la _, ., and Fischer, H., 2017. Glacial/interglacial wetland, biomass burning, and geologic methane emissic 's constrained by dual stable isotopic $\mathrm{CH}_{4}$ ice core records. PNAS, E5778-E5786. www.pnas.org/cgi/ı ‘i/1`.1073/pnas.1613883114

Broccoli, A.J., Dahl, K.A. and Stov'... K.s., 2006. Response of the ITCZ to Northern Hemisphere cooling. Geophysical Research Lette. J3(1). doi:10.1029/2005GL024546

Burls, N.J., Fedorov, A.V., Sigman, D.M., Jaccard, S.L., Tiedemann, R. and Haug, G.H., 2017. Active Pacific meridional overturning circulation (PMOC) during the warm Pliocene. Science advances, 3(9), p.e1700156. doi:10.1126/sciadv.1700156

Cai, W., Lengaigne, M., Borlace, S., Collins, M., Cowan, T., McPhaden, M.J., Timmermann, A., Power, S., Brown, J., Menkes, C. and Ngari, A., 2012. More extreme swings of the South Pacific convergence zone due to greenhouse warming. Nature, 488(7411), pp. 365-369. doi:10.1038/nature11358

Calvert, S.E. and Pedersen, T.F., 2007. Chapter fourteen elemental proxies for palaeoclimatic and palaeoceanographic variability in marine sediments: interpretation and application. Developments in Marine Geology, 1, pp. 567-644. doi:10.1016/S1572-5480(07)01019-6 
Chappellaz, J., Barnola, J.M., Raynaud, D., Korotkevich, Y.S. and Lorius, C., 1990. Ice-core record of atmospheric methane over the past 160,000 years. Nature, 345(6271), pp. 127-131. doi:10.1038/345127a0

Charles, S., Fu, G., Silberstein, R., Mpelasoka, F., McFarlane, D., Hogson, G., Teng, J., Gabrovesk, C., Ali, R., Barron, O., Aryal, A., and Dawes, W., 2015. Hydroclimate of the Pilbara: past, present and future. A report to the Government of Western Australia and industry partners from the CSIRO Pilbara Water Resource Assessment, CSIRO Land and Water, Australia., 114 pp. doi:10.4225/08/584af1c180bda

Cheng, H., Edwards, R.L., Broecker, W.S., Denton, G.H., Kong, X., Wang, Y., Zhang, R. and Wang, X., 2009. Ice age terminations. science, 326(5950), pp. 248-252. doi:10.1126/science.1177840

Cheng, H., Edwards, R.L., Sinha, A., Spötl, C., Yi, L., Chen, S., Kelly, M., Katha ` †, G., Wang, X., Li, X. and Kong, X., 2016. The Asian monsoon over the past 640,000 years and ice age ter nina ions. Nature, 534(7609), pp. 640-646. doi:10.1038/nature18591

Chiang, J.C. and Bitz, C.M., 2005. Influence of high latitude ice cover ${ }^{\text {. th }}$ tharine Intertropical Convergence Zone. Climate Dynamics, 25(5), pp. 477-496. doi:10.1007/s00382-005-七:40-5

Chiang, J.C., Biasutti, M. and Battisti, D.S., 2003. Sensitivity $c^{f+}$.le Atlantic intertropical convergence zone to last glacial maximum boundary conditions. Paleocer $\log a \boldsymbol{p}_{\iota}, 18(4)$. doi:10.1029/2003PA000916

Chiang, J.C., Fang, Y. and Chang, P., 2008. Interhemisphc ic thermal gradient and tropical Pacific climate. Geophysical Research Letters, 35(14). doi: ^ $10_{\llcorner}$Y/2008GL034166

Claussen, M., Brovkin, V., Ganopolski, A., Ku 'tzı, C. and Petoukhov, V., 2003. Climate change in northern Africa: The past is not the future. Climatic C' 'ange, 57(1-2), pp. 99-118. doi:10.1023/A:1022115604225

De Deckker, P., 2001. Late Quaternar, cycl c aridity in tropical Australia. Palaeogeography, Palaeoclimatology, Palaeoecology, 170(1-2) op. 1-9. doi:10.1016/S0031-0182(01)00233-4

De Deckker, P., Barrows, T.T. and F ogers, J., 2014. Land-sea correlations in the Australian region: post-glacial onset of the monsoon in northwestern Western Australia. Quaternary Science Reviews, 105, pp. 181-194. doi:10.1016/j.quascirev.2014.09.030

De Deckker, P., Moros, M., Perner, K. and Jansen, E., 2012. Influence of the tropics and southern westerlies on glacial interhemispheric asymmetry. Nature Geoscience, 5(4), pp.2 66-269. doi:10.1038/ngeo1431

Denniston, R.F., Ummenhofer, C.C., Wanamaker, A.D., Lachniet, M.S., Villarini, G., Asmerom, Y., Polyak, V.J., Passaro, K.J., Cugley, J., Woods, D. and Humphreys, W.F., 2016. Expansion and contraction of the IndoPacific tropical rain belt over the last three millennia. Scientific Reports, 6(1), pp. 1-9. doi:10.1038/srep34485 
Denniston, R.F., Asmerom, Y., Polyak, V.J., Wanamaker Jr, A.D., Ummenhofer, C.C., Humphreys, W.F., Cugley, J., Woods, D. and Lucker, S., 2017. Decoupling of monsoon activity across the northern and southern Indo-Pacific during the Late Glacial. Quaternary Science Reviews, 176, pp. 101-105. doi:10.1016/j.quascirev.2017.09.014

Denton, G.H., Anderson, R.F., Toggweiler, J.R., Edwards, R.L., Schaefer, J.M. and Putnam, A.E., 2010. The last glacial termination. Science, 328(5986), pp.1652-1656. doi:10.1126/science.1184119

DiNezio, P.N. and Tierney, J.E., 2013. The effect of sea level on glacial Indo-Pacific climate. Nature Geoscience, 6(6), pp. 485-491. doi:10.1038/ngeo1823

Dykoski, C.A., Edwards, R.L., Cheng, H., Yuan, D., Cai, Y., Zhang, M., Lin, Y., Qing, J., An, Z. and Revenaugh, J., 2005. A high-resolution, absolute-dated Holocene and deglacial Asian mon - on record from Dongge Cave, China. Earth and Planetary Science Letters, 233(1-2), pp. 71-86. doi:10. 016/ .eps1.2005.01.036

Frederiksen, C.S., Zheng, X. and Grainger, S., 2014. Teleconnections and $\mathrm{f}$ edic ive characteristics of Australian

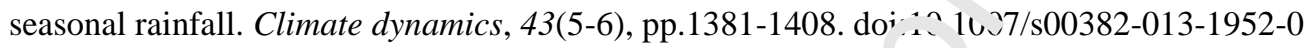

Garbe-Schönberg, D. and Müller, S., 2014. Nano-particulate pressed po v ter tablets for LA-ICP-MS. Journal of Analytical Atomic Spectrometry, 29(6), pp. 990-1000. do ·1 J.J J39/C4JA00007B

Gingele, F.X. and De Deckker, P., 2004. Fingerprintin', Aı straı 's's rivers with clay minerals and the application for the marine record of climate change. Australian Jou, al of Earth Sciences, 51(3), pp. 339-348. doi:10.1111/j.1400-0952.2004.01061.x

Gingele, F.X., De Deckker, P. and Hillenbrar „, Y.L., 2001. Clay mineral distribution in surface sediments between Indonesia and NW Australia—sourc and ıransport by ocean currents. Marine Geology, 179(3-4), pp. 135-146. doi:10.1016/S0025-3227(01)00,?4-3

Gonzalez-Muñoz, M.T., Marti ez-. 'uiz. F., Morcillo, F., Martin-Ramos, J.D. and Paytan, A., 2012. Precipitation of barite by marine bacteria: a pr ssible mechanism for marine barite formation. Geology, 40(8), pp. 675-678. doi:10.1130/G33006.1

Griffith, E.M. and Paytan, A., 2012. Barite in the ocean-occurrence, geochemistry and palaeoceanographic applications. Sedimentology, 59(6), pp. 1817-1835. doi:10.1111/j.1365-3091.2012.01327.x

Griffiths, M.L., Drysdale, R.N., Gagan, M.K., Zhao, J.X., Ayliffe, L.K., Hellstrom, J.C., Hantoro, W.S., Frisia, S., Feng, Y.X., Cartwright, I. and Pierre, E.S., 2009. Increasing Australian-Indonesian monsoon rainfall linked to early Holocene sea-level rise. Nature Geoscience, 2(9), pp. 636-639. doi:10.1038/ngeo605

Guo, Z., Zhou, X. and Wu, H., 2012. Glacial-interglacial water cycle, global monsoon and atmospheric methane changes. Climate Dynamics, 39(5), pp. 1073-1092. doi:10.1007/s00382-011-1147-5 
Hanebuth, T.J. and Henrich, R., 2009. Recurrent decadal-scale dust events over Holocene western Africa and their control on canyon turbidite activity (Mauritania). Quaternary Science Reviews, 28(3-4), pp. 261-270. doi:10.1016/j.quascirev.2008.09.024

Haug, G.H., Hughen, K.A., Sigman, D.M., Peterson, L.C. and Röhl, U., 2001. Southward migration of the intertropical convergence zone through the Holocene. Science, 293(5533), pp. 1304-1308. doi:10.1126/science.1059725

Heirtzler, J.R., 1974. Aeolian transport of dust off western Australia: in Veevers, J. J., J. R. Heirtzler et al., Initial reports of the Deep Sea Drilling Project: v. 27 (U. S. Government Printing Office), Washington, p. 397-399.

Henrich, R., Hanebuth, T.J.J., Cherubini, Y., Krastel, S., Pierau, R. and Zühlsdort , C., 2010. Climate-induced turbidity current activity in NW-African canyon systems. In Submarine $r$ ass $r$ ovements and their consequences (pp. 447-459). Springer, Dordrecht. doi:10.1016/j.jop.’ 715.18 .011

Hesse, P.P., Magee, J.W. and van der Kaars, S., 2004. Late Quaternar _' 'mı tes of the Australian arid zone: a review. Quaternary International, 118, pp. 87-102. doi:10.1016/S1040 61.'(03)00132-0

Hesse, P.P. and McTainsh, G.H., 2003. Australian dust deposit : no lern processes and the Quaternary record. Quaternary Science Reviews, 22(18-19), pp.2007-2u '5. u i:10.1016/S0277-3791(03)00164-1

Holbourn, A., Kuhnt, W., Kawamura, H., Jian, Z., Grootes, P., Erlenkeuser, H. and Xu, J., 2005. Orbitally paced paleoproductivity variations in the Timor S . . an 'ndonesian Throughflow variability during the last 460 kyr.

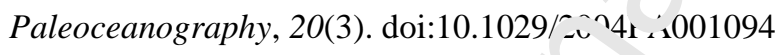

Jansen, J.H.F., Kuijpers, A. and Troelstra, :R., 1986. A mid-Brunhes climatic event: Long-term changes in global atmosphere and ocean circulatio. Scl ?nce, 232(4750), pp. 619-622. doi:10.1126/science.232.4750.619

Jansen, J.H.F., Van der Gaast, C.J., Kos` sr, B. and Vaars, A.J., 1998. CORTEX, a shipboard XRF-scanner for element analyses in split serir ent cores. Marine Geology, 151(1-4), pp. 143-153. doi:10.1016/S00253227(98)00074-7

Jickells, T.D., An, Z.S., Andersen, K.K., Baker, A.R., Bergametti, G., Brooks, N., Cao, J.J., Boyd, P.W., Duce, R.A., Hunter, K.A. and Kawahata, H., 2005. Global iron connections between desert dust, ocean biogeochemistry, and climate. Science, 308(5718), pp. 67-71. doi:10.1126/science.1105959

Kathayat, G., Cheng, H., Sinha, A., Spötl, C., Edwards, R.L., Zhang, H., Li, X., Yi, L., Ning, Y., Cai, Y. and Lui, W.L., 2016. Indian monsoon variability on millennial-orbital timescales. Scientific reports, 6, p.24374. doi:10.1038/srep24374 
Kawamura, H., Holbourn, A. and Kuhnt, W., 2006. Climate variability and land-ocean interactions in the Indo Pacific Warm Pool: a 460-ka palynological and organic geochemical record from the Timor Sea. Marine Micropaleontology, 59(1), pp. 1-14. doi:10.1016/j.marmicro.2005.09.001

Keep, M., Holbourn, A., Kuhnt, W. and Gallagher, S.J., 2018. Progressive Western Australian collision with Asia: implications for regional orography, oceanography, climate and marine biota. Journal of the Royal Society of Western Australia, 101, pp. 1-16.

Kelly, M.J., Edwards, R.L., Cheng, H., Yuan, D., Cai, Y., Zhang, M., Lin, Y. and An, Z., 2006. High resolution characterization of the Asian Monsoon between 146,000 and 99,000 years BP from Dongge Cave, China and global correlation of events surrounding Termination II. Palaeogeography, rlaeoclimatology, Palaeoecology, 236(1-2), pp. 20-38. doi:10.1016/j.palaeo.2005.11.042

Kershaw, A.P., van der Kaars, S. and Moss, P.T., 2003. Late Quaternary M 'ankı vitch-scale climatic change and variability and its impact on monsoonal Australasia. Marine Ge in rv, 201(1-3), pp. 81-95. doi:10.1016/S00253227(03)00210-X

Kuhnt, W., Holbourn, A., Xu, J., Opdyke, B., De Deckker, P., ’̈̈.ll, U. and Mudelsee, M., 2015. Southern Hemisphere control on Australian monsoon vari silı y du. ing the late deglaciation and Holocene. Nature communications, 6(1), pp. 1-7. doi:10.1038/ncomms`916

Kuhnt, W., Holbourn, A., Schönfeld, J., Lindhors*, K., Sallagher, S., Keep, M., Sadekov, A., Dunlea, A., Clemens, S., Wilkens, R., Sarnthein, M., Leutert, T.. с. эn, P., Maicher, D., Manceau, R., Dillon, A., Gonzalez, J.-L., Fabian, S., McCaffrey, J., Kochhan.. K., Lübbers, J., Jöhnck, J., Hingst, J., Parplies, K., Koppe, M., Steffen, S., Schultz, J., Heinrich, S., Averes, T. ar u Evers, F., 2018. Cruise Report Sonne 257, WACHEIO - Western Australian Climate Histc -v f >m F astern Indian Ocean Sediment Archives, Darwin - Fremantle, May 12, 2017 June 04, 2017. Institut für Cer wissenschaften, Christian-Albrechts-Universität Kiel, 260 pp. doi:10.2312/cr_so257

Lauterbach, S., Andersen, N., Wang, Y. V., Blanz, T., Larsen, T., \& Schneider, R. R. (2020). An 130 kyr record of surface water temperature and $\delta^{18} \mathrm{O}$ from the northern Bay of Bengal: Investigating the linkage between Heinrich events and Weak Monsoon Intervals in Asia. Paleoceanography and Paleoclimatology, 35, e2019PA003646. doi:10.1029/2019PA003646

Lechler, P.J. and Desilets, M.O., 1987. A review of the use of loss on ignition as a measurement of total volatiles in whole-rock analysis. Chemical Geology, 63(3-4), pp. 341-344. doi:10.1016/0009-2541(87)90171-9 
Lisiecki, L.E. and Raymo, M.E., 2005. A Pliocene-Pleistocene stack of 57 globally distributed benthic $\delta 180$ records. Paleoceanography, 20(1). doi:10.1029/2004PA001071

Liu, L., Chen, J., Chen, Y., Ji, J. and Lu, H., 2002. Variation of Zr/Rb ratios on the Loess Plateau of Central China during the last 130000 years and its implications for winter monsoon. Chinese Science Bulletin, 47(15), pp. 1298-1302. doi:10.1360/02tb9288

Liu, Z., Wen, X., Brady, E.C., Otto-Bliesner, B., Yu, G., Lu, H., Cheng, H., Wang, Y., Zheng, W., Ding, Y. and Edwards, R.L., 2014. Chinese cave records and the East Asia summer monsoon. Quaternary Science Reviews, 83, pp. 115-128. doi:10.1016/j.quascirev.2013.10.021

Loulergue, L., Schilt, A., Spahni, R., Masson-Delmotte, V., Blunier, T., Lemieux, ? ., Barnola, J.M., Raynaud, D., Stocker, T.F. and Chappellaz, J., 2008. Orbital and millennial-scale featu es ol atmospheric CH 4 over the past 800,000 years. Nature, 453(7193), pp. 383-386. doi:10.1038/nature)( 950

Lu, J., Vecchi, G.A. and Reichler, T., 2007. Expansion of the Hadley _... 'llı.er global warming. Geophysical Research Letters, 34(6). doi:10.1029/2006GL028443

Lüthi, D., Le Floch, M., Bereiter, B., Blunier, T., Barnola, J. ․ sie šnthaler, D., Raynaud, J., Jouzel, H., Fischer, K., Kawamura and Stocker, T. F., 2008. High-resolv .1on zarb. n dioxide concentration record 650,000-800,000 years before present. Nature, 453(7193), pp. 379-3〉_ doi:10.1038/nature06949

Lübbers, J., Kuhnt, W., Holbourn, A.E., Bolton, r. , L ay, E., Usui, Y., Kochhann, K.G., Beil, S. and Andersen, N.,

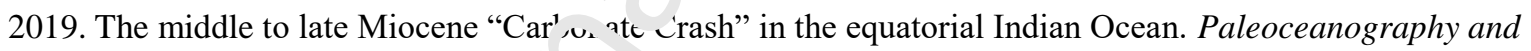
Paleoclimatology, 34(5), pp. 813-85: do1.10.1029/2018PA003482

McTainsh, G.H., 1989. Quaternary ae`'ian r'ust processes and sediments in the Australian region. Quaternary

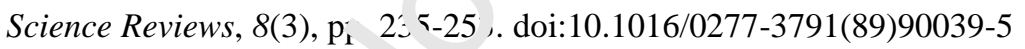

Mohtadi, M., Oppo, D.W., Steinke. ,., Stuut, J.B.W., De Pol-Holz, R., Hebbeln, D. and Lückge, A., 2011. Glacial to Holocene swings of the Australian-Indonesian monsoon. Nature Geoscience, 4(8), pp. 540-544. doi:10.1038/ngeo1209

Mohtadi, M., Prange, M. and Steinke, S., 2016. Palaeoclimatic insights into forcing and response of monsoon rainfall. Nature, 533(7602), pp. 191-199. doi:10.1038/nature17450

Muller, J., Kylander, M., Martinez-Cortizas, A., Wüst, R.A., Weiss, D., Blake, K., Coles, B. and Garcia-Sanchez, R., 2008. The use of principle component analyses in characterising trace and major elemental distribution in a 55 kyr peat deposit in tropical Australia: implications to paleoclimate. Geochimica et Cosmochimica Acta, 72(2), pp. 449-463. doi:10.1016/j.gca.2007.09.028 
Muller, J., Kylander, M., Wüst, R.A., Weiss, D., Martinez-Cortizas, A., LeGrande, A.N., Jennerjahn, T., Behling, H., Anderson, W.T. and Jacobson, G., 2008. Possible evidence for wet Heinrich phases in tropical NE Australia: the Lynch's Crater deposit. Quaternary Science Reviews, 27(5-6), pp. 468-475. doi:10.1016/j.quascirev.2007.11.006

Muller, J., McManus, J.F., Oppo, D.W. and Francois, R., 2012. Strengthening of the Northeast Monsoon over the Flores Sea, Indonesia, at the time of Heinrich event 1. Geology, 40(7), pp. 635-638. doi:10.1130/G32878.1

Paillard, D., Labeyrie, L. and Yiou, P., 1996. Macintosh program performs time-series analysis. Eos, Transactions American Geophysical Union, 77(39), pp. 379-379. doi:10.1029/96EO00259

Partin, J.W., Cobb, K.M., Adkins, J.F., Clark, B. and Fernandez, D.P., 2007. Milı. - nial-scale trends in west Pacific warm pool hydrology since the Last Glacial Maximum. Nature, 449(716 ), pp 452-455. doi:10.1038/nature06164

Poulton, S.W., Raiswell, R., 2002. The low-temperature geochemical - y. ${ }^{1} \mathrm{e} \iota \mathrm{f}$ iron: From continental fluxes to marine sediment deposition. Am. J. Sci. 302, 774-805. doi:10.2475/aj .3v.' 9.774

Pusey, B.J. and Kath, J., 2015. Environmental Water Managen. ar.c is the Fitzroy River Valley Information availability, knowledge gaps and research needs $U n$, ubı. hed report to the Department of Water, Western Australia. doi:10.13140/RG.2.1.3739.4966

Rea, D.K., 1994. The paleoclimatic record provid _.' by . olian deposition in the deep sea: The geologic history of wind. Reviews of Geophysics, 32(2), pr. 1 <9-, $\rightarrow 5$. doi:10.1029/93RG03257

Revill, A.T., Jones, N.L., Hipsey, M.J., Bı ce, L.C., Silberstein, R.P., Furnas, M., Donn, M., Espinosa, A., Gruber, R. and Zhou, W., 2017. Terrestrial- 7 cea ı Linkages: the role of rivers and estuaries in sustaining marine productivity in the Kimb $\cdot$ le 2 Re ort of Project, 2(6).

Rhodes, R.H., Brook, E.J., Chian`. '.H.C., Bunier, T., Maselli, O.J., McConnell, J.R., Romanini, J.R., and Severinghaus, J.P., 2015. Enhanced tropical methane production in response to iceberg discharge in the North Atlantic. Science 348/6238, pp. 1016-1019, doi:10.1126/science.1262005

Risbey, J.S., Pook, M.J., McIntosh, P.C., Wheeler, M.C. and Hendon, H.H., 2009. On the remote drivers of rainfall variability in Australia. Monthly Weather Review, 137(10), pp. 3233-3253. doi:10.1175/2009MWR2861.1

Rosenthal, Y., Holbourn, A.E. and Kulhanek, D.K., and the Expedition 363 Scientists, 2017. Expedition 363 Preliminary Report: Western Pacific Warm Pool. International Ocean Discovery Program. pp. 11-13. doi:10.14379/iodp.pr.363.2017 
Rosenthal, Y., Holbourn, A.E., Kulhanek, D.K., and the Expedition 363 Scientists, 2018. Western Pacific Warm Pool. Proceedings of the International Ocean Discovery Program, 363: College Station, TX (International Ocean Discovery Program). doi:10.14379/iodp.proc.363.2018

Rosenthal, Y., Oppo, D.W. and Linsley, B.K., 2003. The amplitude and phasing of climate change during the last deglaciation in the Sulu Sea, western equatorial Pacific. Geophysical Research Letters, 30(8). doi:10.1029/2002GL016612

Sarnthein, M., Grootes, P.M., Holbourn, A., Kuhnt, W. and Kühn, H., 2011. Tropical warming in the Timor Sea led deglacial Antarctic warming and atmospheric CO2 rise by more than 500 yr. Earth and Planetary Science Letters, 302(3-4), pp. 337-348. doi:10.1016/j.eps1.2010.12.021

Schneider, T., Bischoff, T. and Haug, G.H., 2014. Migrations and dynamics of he ir ertropical convergence zone. Nature, 513(7516), pp. 45-53. doi:10.1038/nature13636

Schröder, J.F., Holbourn, A., Kuhnt, W. and Küssner, K., 2016. Varia ‘ ‘ 's 1. sea surface hydrology in the southern Makassar Strait over the past 26 kyr. Quaternary Science Revirws, 154, pp. 143-156. doi:10.1016/j.quascirev.2016.10.018

Schröder, J.F., Kuhnt, W., Holbourn, A., Beil, S., Zhar s, t , H七.drizan, M. and Xu, J., 2018. Deglacial warming and hydroclimate variability in the central Indonesian Aı hipelago. Paleoceanography and Paleoclimatology, 33(9), pp.974-993. doi:10.1029/2018PA003323

Seidel, D. J., Fu, Q., Randel, W. J. \& Reichle , ? J., L008. Widening of the tropical belt in a changing climate. Nature Geosciences 1, 21-24.

Shakun, J.D., Clark, P.U., He, F., Maı ’tt, \&.A., Mix, A.C., Liu, Z., Otto-Bliesner, B., Schmittner, A. and Bard, E., 2012. Global warming $\mathrm{p}$. ${ }^{\circ} \mathrm{e}^{\prime}{ }^{\mathrm{e}} \mathrm{d} \mathrm{b}$ /ncreasing carbon dioxide concentrations during the last deglaciation. Nature, 484(7392), pp. 49-54 doi:10.1038/nature10915

Sniderman, J.K., Brown, J.R., Woodhead, J.D., King, A.D., Gillett, N.P., Tokarska, K.B., Lorbacher, K., Hellstrom, J., Drysdale, R.N. and Meinshausen, M., 2019. Southern Hemisphere subtropical drying as a transient response to warming. Nature Climate Change, 9(3), pp. 232-236. doi:10.1038/s41558-019-0397-9

Stager, J.C., Ryves, D.B., Chase, B.M. and Pausata, F.S., 2011. Catastrophic drought in the Afro-Asian monsoon region during Heinrich event 1. Science, 331(6022), pp. 1299-1302. doi:10.1126/science.1198322

Stríkis, N.M., Cruz, F.W., Barreto, E.A., Naughton, F., Vuille, M., Cheng, H., Voelker, A.H., Zhang, H., Karmann, I., Edwards, R.L. and Auler, A.S., 2018. South American monsoon response to iceberg discharge in the North 
Atlantic. Proceedings of the National Academy of Sciences, 115(15), pp. 3788-3793.

doi:10.1073/pnas.1717784115

Stuiver, M., Reimer, P.J. and Reimer, R.W., 2019. Calib Radiocarbon calibration 7.0. World Wide Web: http://calib. qub. ac. uk/calib/. Accessed, 1 .

Stuut, J.B.W., Temmesfeld, F. and De Deckker, P., 2014. A 550 ka record of aeolian activity near North West Cape, Australia: inferences from grain-size distributions and bulk chemistry of SE Indian Ocean deep-sea sediments. Quaternary Science Reviews, 83, pp. 83-94. doi:10.1016/j.quascirev.2013.11.003.

Sudmeyer, R., 2016. Climate in the Pilbara, Bulletin 4873, Department of Agriculture and Food, Western Australia, Perth, 46 pp.

Suppiah, R., 1992. The Australian summer monsoon: a review. Progress in Ph sicaı Geography, 16(3), pp.283-318. doi:10.1177/030913339201600302

Taylor, S.R. and McLennan, S.M., 1985. The continental crust: its cor ${ }_{*}$ sit on and evolution. Blackwell Scientific, Oxford, $312 \mathrm{pp}$.

Tjallingii, R., Röhl, U., Kölling, M. and Bickert, T., 2007. Inflı ər.ce sf the water content on X-ray fluorescence corescanning measurements in soft marine sediments Gt cht. nistry, Geophysics, Geosystems, 8(2). doi:10.1029/2006GC001393

Thirumalai, K., Clemens, S.C. and Partin, J.W., 2 2:?. N.athane, Monsoons, and Modulation of Millennial-Scale Climate. Geophysical Research Letters 4,79, p.e2020GL087613. doi:10.1029/2020GL087613

Tory, K.J., Dare, R.A., 2015. Sea surface 、 mperdture thresholds for tropical cyclone formation. J. Clim. 28, 81718183. doi:10.1175/JCLI-D-14-0`‘37.

Turekian, K.K. and Wedepohl, K.I. 19 j1. Distribution of the elements in some major units of the earth's crust. Geological Society of Americr Bulletin, 72(2), pp. 175-192. doi:10.1130/00167606(1961)72[175:DOTEIS]2.0.CO;2

Turney, C.S., Haberle, S., Fink, D., Kershaw, A.P., Barbetti, M., Barrows, T.T., Black, M., Cohen, T.J., Correge, T., Hesse, P.P. and Hua, Q., 2006. Integration of ice-core, marine and terrestrial records for the Australian Last Glacial Maximum and Termination: a contribution from the OZ INTIMATE group. Journal of Quaternary Science: Published for the Quaternary Research Association, 21(7), pp. 751-761. doi:10.1002/jqs.1073

Vogel, W. and Kuipers, G., 1987. A pre-calibrated program for geological applications, Phillips New Developments. X-Ray Spectrometry., 11, pp. 2-8. 
Wang, Y.J., Cheng, H., Edwards, R.L., An, Z.S., Wu, J.Y., Shen, C.C. and Dorale, J.A., 2001. A high-resolution absolute-dated late Pleistocene monsoon record from Hulu Cave, China. Science, 294(5550), pp. 2345-2348. doi:10.1126/science. 1064618

Wang, Y., Cheng, H., Edwards, R.L., Kong, X., Shao, X., Chen, S., Wu, J., Jiang, X., Wang, X. and An, Z., 2008. Millennial-and orbital-scale changes in the East Asian monsoon over the past 224,000 years. Nature, 451(7182), pp. 1090-1093. doi:10.1038/nature06692

Webster, P.J., Magana, V.O., Palmer, T.N., Shukla, J., Tomas, R.A., Yanai, M.U. and Yasunari, T., 1998. Monsoons: Processes, predictability, and the prospects for prediction. Journal of Geophysical Research: Oceans, 103(C7), pp. 14451-14510.doi:10.1029/97JC02719

Wedepohl, K., 1971. Geochemistry: Holt. Rinehart and Winston, New York., 2. 1 pp

Weltje, G.J. and Tjallingii, R., 2008. Calibration of XRF core scanners for ! ' lant tative geochemical logging of sediment cores: Theory and application. Earth and Planetary Sr:.. re :etters, 274(3-4), pp. 423-438. doi:10.1016/j.eps1.2008.07.054

Wyrwoll, K.H., Liu, Z., Chen, G., Kutzbach, J.E. and Liu, X.. ‘ $9^{r}, 7$. Sensitivity of the Australian summer monsoon to tilt and precession forcing. Quaternary Science F evl ws, ¿ 5(25-28), pp. 3043-3057. doi:10.1016/j.quascirev.2007.06.026

Yuan, D., Cheng, H., Edwards, R.L., Dykoski, C • K`'1y, M.J., Zhang, M., Qing, J., Lin, Y., Wang, Y., Wu, J. and Dorale, J.A., 2004. Timing, duration, a' u' ratıutions of the last interglacial Asian monsoon. Science, 304(5670), pp. 575-578. doi:10.1126/science.1C''122

Zhang, P., Xu, J., Holbourn, A., Kuhn., W., Beil, S., Li, T., Xiong, Z., Dang, H., Yan, H., Pei, R. and Ran, Y., 2020 (in press). Indo-Pacific $\mathrm{r}_{\mathrm{r}} \mathrm{drc} \cdot \mathrm{lim}$ te in response to changes of the Intertropical Convergence Zone: Discrepancy on precession an'. obliquity bands over the last 410 kyr. Journal of Geophysical Research: Atmospheres, p.e2019JD032125. doi:10.1029/2019JD032125

Figure 1. A. Main rivers discharging sediment to the northwestern Australian margin and average Holocene-MIS-6 sedimentation rates $(\mathrm{cm} / \mathrm{kyr}$ ) along the margin. Water depth scale in $\mathrm{m}$. B. Summer monsoonal (February) vegetation and precipitation patterns. Average sedimentation rates (cm/kyr) are from Sonne 257 cores offshore Australia (from Keep et al., 2018; Kuhnt et al., 2018). February precipitation is based on 30 yr standard climatology (1961-1990) in $\mathrm{mm} / \mathrm{month}$ from Australian Bureau of Meteorology (2010). Satellite Image is from February 2004 from NASA Blue Marble.

Figure 2. Location of Cores SO257-18548 and -18571 and IODP Site U1482 offshore northwestern Australia (A). Base map created using www.maps-for-free.com. Detailed maps (B-C) show positions of coring sites in relation to 
adjacent main rivers and concentrations of main terrigenous elements ( $\mathrm{Si}, \mathrm{Al}, \mathrm{Fe}, \mathrm{K}$ and $\mathrm{Ti})$ ) in fine-grained $(<63 \mu \mathrm{m})$ fractions of terrigenous material in marine sediment cores (B) and river sediments (C). Approximate extension of glacial Fitzroy River on shelf is indicated by blue dashed line in B.

Figure 3. Correlation of benthic foraminiferal $\delta^{18} \mathrm{O}$ from Core SO257-18548 and Site U1482 to benthic isotope stack LR04 (Lisiecki and Raymo, 2005). Dashed black lines indicate tie points used to derive age model. Dashed red lines indicate $\mathrm{AMS}^{14} \mathrm{C}$ ages. Orange dashed lines indicate biostratigraphic datums: $\mathrm{B}=\mathrm{Base}, \mathrm{T}=\mathrm{Top}$ (from Rosenthal et al., 2018).

Figure 4. Correlation of benthic foraminiferal $\delta^{18} \mathrm{O}$ of Core SO257-18571 to the benthic isotope stack LR04 (Lisiecki and Raymo, 2005). Dashed black lines indicate tie points used to derive age model. Dashed red lines indicate $\mathrm{AMS}^{14} \mathrm{C}$ ages.

Figure 5. Temporal evolution of XRF scanner derived elemental ratios and ben ic foraminiferal $\delta^{18} \mathrm{O}$. MIS $=$ marine isotope stages. (A-B) $\log (\mathrm{Zr} / \mathrm{Rb}$ ) from Core SO257-18548 and Site U1: ' 2 (orange) and from Core SO257-18571 (red); (C-D) $\log (\mathrm{Terr} / \mathrm{Ca})$ from Core SO257-18548 and Site U1482 lack and from Core SO257-18571 (purple); (E-F) benthic $\delta^{18} \mathrm{O}$ from SO257-18548 and Site U1482 (dark blue) a d h $\mathrm{m}$ Core SO257-18571 (light blue). Blue shading indicates marine isotope glacial stages (MIS), followir g I.1s ecki and Raymo (2005).

Figure 6. Comparison of monsoonal discharge ( $\log \left({ }^{-}\right.$err/ ' a a)) in composite record from Core SO157-18548 and Site U1482 with evolution of Antarctic temperatures (Epica Do. .e Concordia (EDC) $\delta$ D from Bazin et al., 2013) and Northern Hemisphere monsoon intensity (Chinese spe ' ' them $\delta^{18} \mathrm{O}$ record from Dongge, Hulu and Sanbao Caves. Wang et al., 2001,2008; Dykoski et al., 2005; Ktil et al., 2006; Cheng et al., 2009, 2016). Note that monsoonal discharge record is tuned to LR04 stack (Lis : cki a.ld Raymo, 2005) and, thus, independent of EDC ice core age model. Glacial Terminations I-V in LR04 s ack are marked with blue (onset) and red (end) dashed lines; corresponding ages are 18-9 ka (Term:natio. I), 135-126 ka (Termination II), 252-240 ka (Termination III), 341-329 ka (Terminations IV) and 431-410 кa (- Jermination V).

Figure 7. Comparison of terriger $\cdots$, discharge records from Cores SO257-18571, SO257-18548 and Site U1482 to external and internal forcing mechanisms. (A) Insolation $21^{\text {st }}$ of September at $20^{\circ} \mathrm{S}$; (B) Insolation gradient between 10 and $30^{\circ} \mathrm{S}$; (C) $\log (\mathrm{Terr} / \mathrm{Ca})$ from Core SO257-18548 and Site U1482 (black); (D) $\log (\mathrm{Terr} / \mathrm{Ca}$ ) from Core SO257-18571 (purple); (E) EPICA Dome Concordia (EDC) $\mathrm{CH}_{4}$ record (Loulergue et al., 2008); (F) $\mathrm{EDC} \mathrm{CO}_{2}$ record (Lüthi. et al., 2008.). Green shading marks monsoonal peaks associated with $p \mathrm{CO}_{2}$ maxima occurring at austral spring insolation maxima and minimal gradient between 10 and $30^{\circ} \mathrm{S}$ insolation, which favors southward migration of the ITCZ.

Table 1. AMS ${ }^{14} \mathrm{C}$ dates from analysis of Globigerinoides ruber (white)

Kiel AMS

Laboratory

Depth Foraminife

Uncorr. ${ }^{14} \mathrm{C}$ Age Error Reservoir

Calibrated Age

Number

(cm) ral species

(years B.P.)

bar Age (years)

(years B.P.) 


\begin{tabular}{|c|c|c|c|c|c|c|c|}
\hline KIA 53786 & $\begin{array}{l}\text { SO257- } \\
18548\end{array}$ & 70 & G. ruber & 11765 & 45 & 510 & 13114 \\
\hline KIA 53787 & $\begin{array}{l}\text { SO257- } \\
18548\end{array}$ & 100 & G. ruber & 18305 & 70 & 1600 & 20154 \\
\hline KIA 53788 & $\begin{array}{l}\text { SO257- } \\
18571\end{array}$ & 140 & G. ruber & 9980 & 40 & 250 & 10738 \\
\hline KIA 53789 & $\begin{array}{l}\text { SO257- } \\
18571\end{array}$ & 190 & G. ruber & 18830 & 75 & 1600 & 20778 \\
\hline
\end{tabular}

Table 2. Age tie points to LR04 benthic isotope stack (Lisiecki and Raymo, 2005)

\begin{tabular}{|c|c|c|c|c|c|}
\hline \multicolumn{2}{|c|}{ SO257-18548 and U1482 } & \multicolumn{3}{|c|}{ SO257-18571 } & \multirow{2}{*}{ Descriptıo - of tie points } \\
\hline Core Depth & $\delta^{18} \mathrm{O}(\%$ & Core Depth & $\delta^{18} \mathrm{O}(\%$ & Age (ka) & \\
\hline (m) & VPDB) & $(\mathrm{m})$ & VPDB) & & \\
\hline 2.7 & 3.68 & 3.6 & 3.3 & 62 & $\delta^{1} \mathrm{O} n$. ximum in center of MIS 4 \\
\hline 3.7 & 3.11 & 5.1 & 3.05 & 87 & $i^{18} \mathrm{O}$ maximum in center of MIS $5 b$ \\
\hline 4.4 & 3.11 & 6.9 & 3.07 & 109 & $c^{18} \mathrm{O}$ maximum in center of MIS $5 \mathrm{~d}$ \\
\hline 5.1 & 3.76 & 9.2 & 3.6 & 135 & ᄀnset of Termination II \\
\hline 6.5 & 3.4 & 11.1 & 3.12 & 185 & Onset of MIS 6 \\
\hline 7.6 & 3.49 & 14.4 & 3.3 & 23 & Onset of Termination IIIb \\
\hline 8.4 & 3.56 & 16.2 & 3.17 & 252 & Onset of Termination IIIa \\
\hline 9 & 3.49 & 16.9 & 3.1 & 277 & Onset of second $\delta^{18} \mathrm{O}$ maximum in MIS 8 \\
\hline 9.7 & 3.38 & 17.7 & 2.9 & 294 & First $\delta^{18} \mathrm{O}$ maximum in MIS 8 \\
\hline 10.5 & 2.86 & 19.3 & 4 , & 318 & End of first $\delta^{18} \mathrm{O}$ minimum in MIS 9 \\
\hline 11.7 & 3.73 & & & 342 & Onset of Termination IV \\
\hline 13.9 & 3.3 & & & 392 & End of first $\delta^{18} \mathrm{O}$ minimum in MIS 11 \\
\hline 15.5 & 3.8 & & & 433 & Onset of Termination $\mathrm{V}$ \\
\hline
\end{tabular}

Table 3. Concentration of main « rry wulous elements in Cores SO257-18548 and -18571 and close by rivers. Fitz = Fitzroy River, Ashb = Ashburton R; ver, Fort = Fortescue River, Gasc = Gascoyne River

$\begin{array}{lllllllllll}\text { Elements } & \mathbf{1 8 5 4 8} & \text { Derby } & \text { Fitz1 } & \text { Fitz2 } & \mathbf{1 8 5 7 1} & \text { Ashb1 } & \text { Fort1 } & \text { Fort2 } & \text { Gasc1 } & \text { Gasc2 } \\ & (\boldsymbol{\%}) & (\%) & (\%) & (\%) & (\boldsymbol{\%}) & (\%) & (\%) & (\%) & (\%) & (\%) \\ \mathrm{Si} & \mathbf{6 5 . 7 2} & 60.28 & 79.67 & 77.34 & \mathbf{6 7 . 3 7} & 68.84 & 66.08 & 65.63 & 63.18 & 66.38 \\ \mathrm{Al} & \mathbf{2 1 . 7 5} & 24.35 & 11.81 & 13.19 & \mathbf{1 9 . 7 2} & 15.69 & 14.15 & 14.27 & 22.10 & 19.26 \\ \mathrm{Fe} & \mathbf{8 . 5 6} & 10.90 & 5.25 & 6.04 & \mathbf{9 . 3 0} & 12.03 & 16.85 & 17.27 & 11.08 & 10.44 \\ \mathrm{~K} & \mathbf{3 . 0 6} & 3.44 & 2.05 & 2.39 & \mathbf{2 . 3 7} & 2.33 & 1.72 & 1.71 & 2.50 & 2.43 \\ \mathrm{Ti} & \mathbf{0 . 9 0} & 1.03 & 1.22 & 1.03 & \mathbf{1 . 2 4} & 1.10 & 1.21 & 1.12 & 1.14 & 1.50\end{array}$

\section{Key findings}

- $\quad$ Rapid intensification of Australian monsoon at end of glacial terminations I to IV 
- Monsoon intensification coincided with atmospheric $\mathrm{CO}_{2}$ increase

- Austral spring insolation drove southward shift of ITCZ and monsoon intensification

- Formation of regional heat lows instrumental for monsoonal hydroclimate

- Aeolian dust dominant during glacials and MIS 5a-d south of $20^{\circ} \mathrm{S}$. 
Figure 1
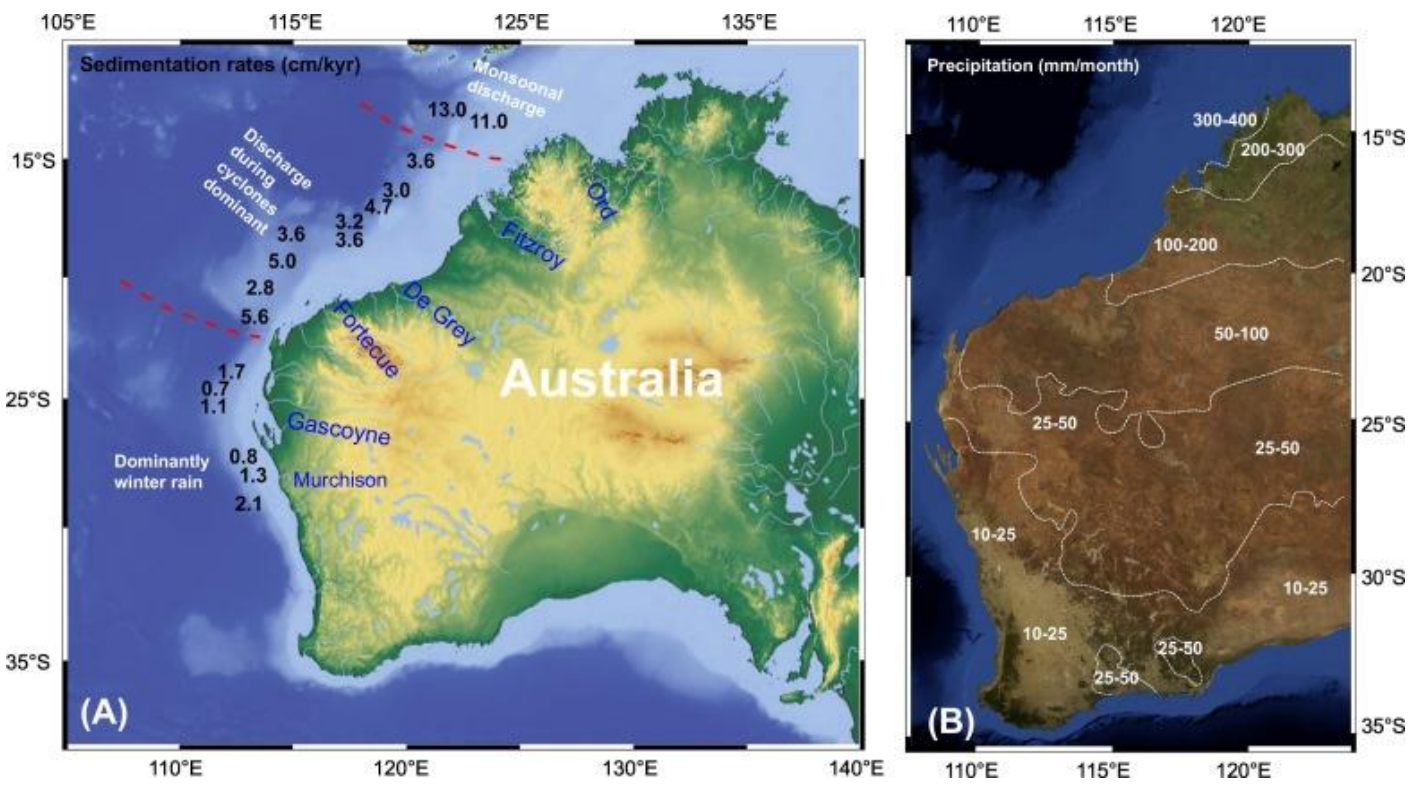

Figure 2

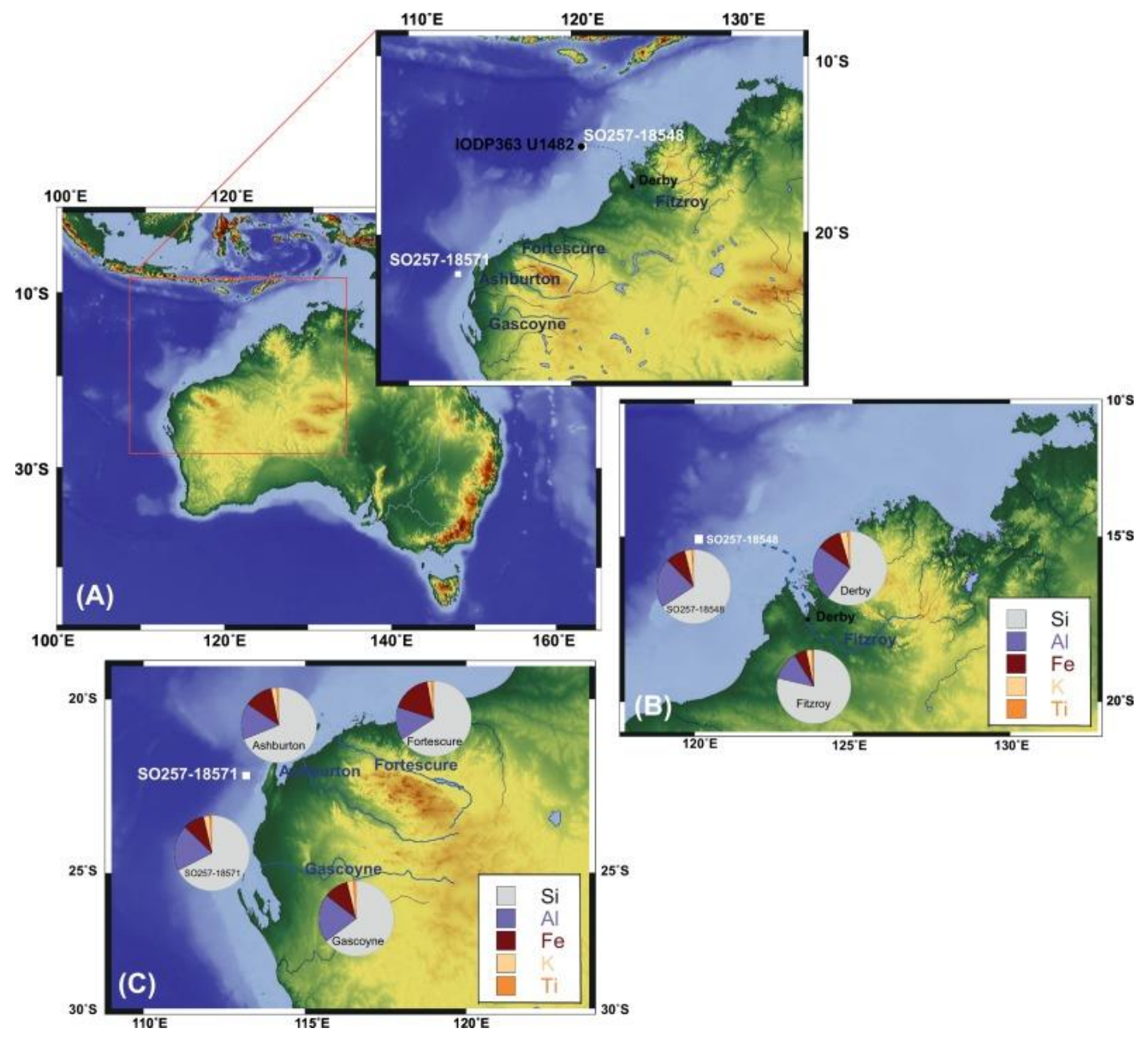


Figure 3

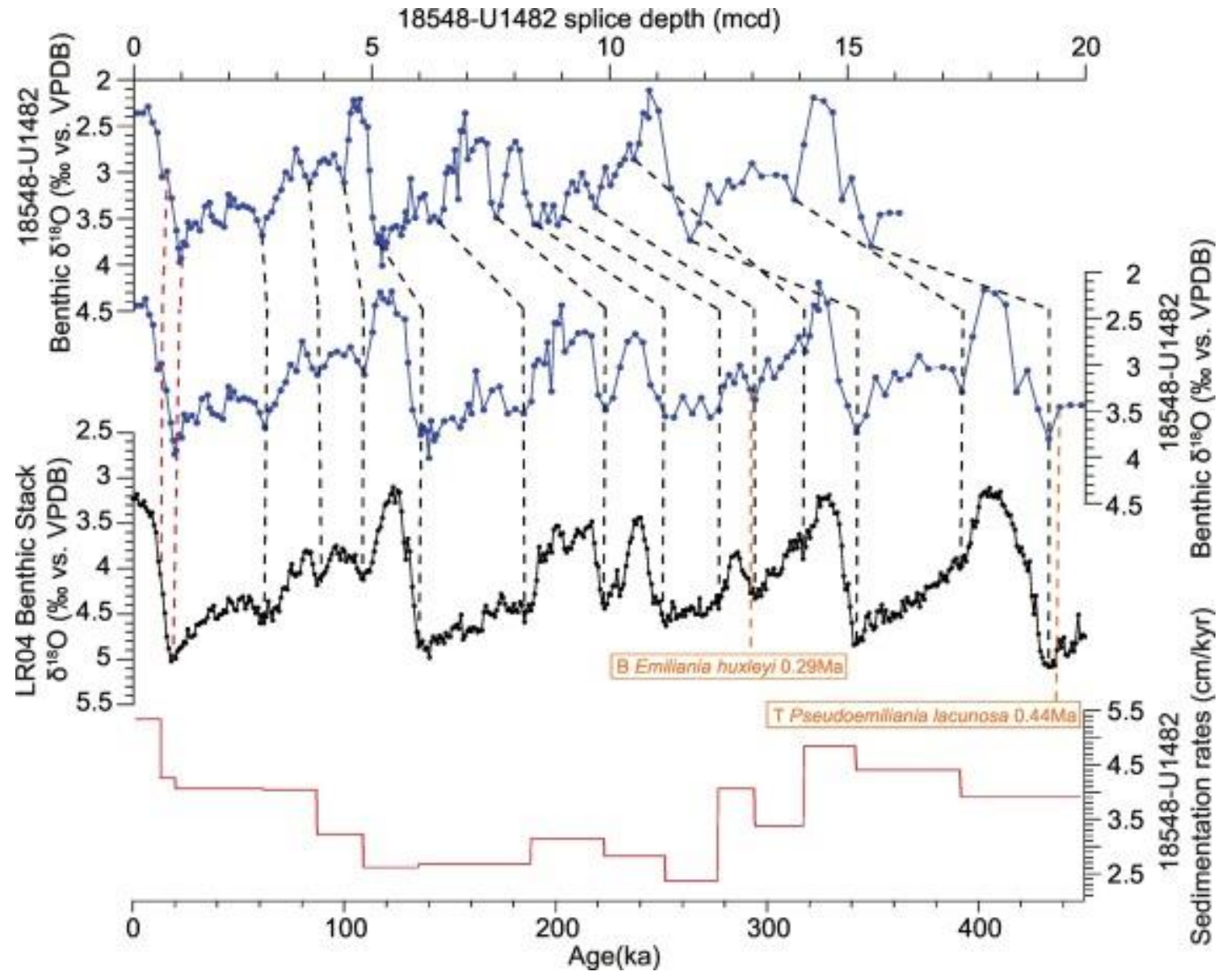


Figure 4

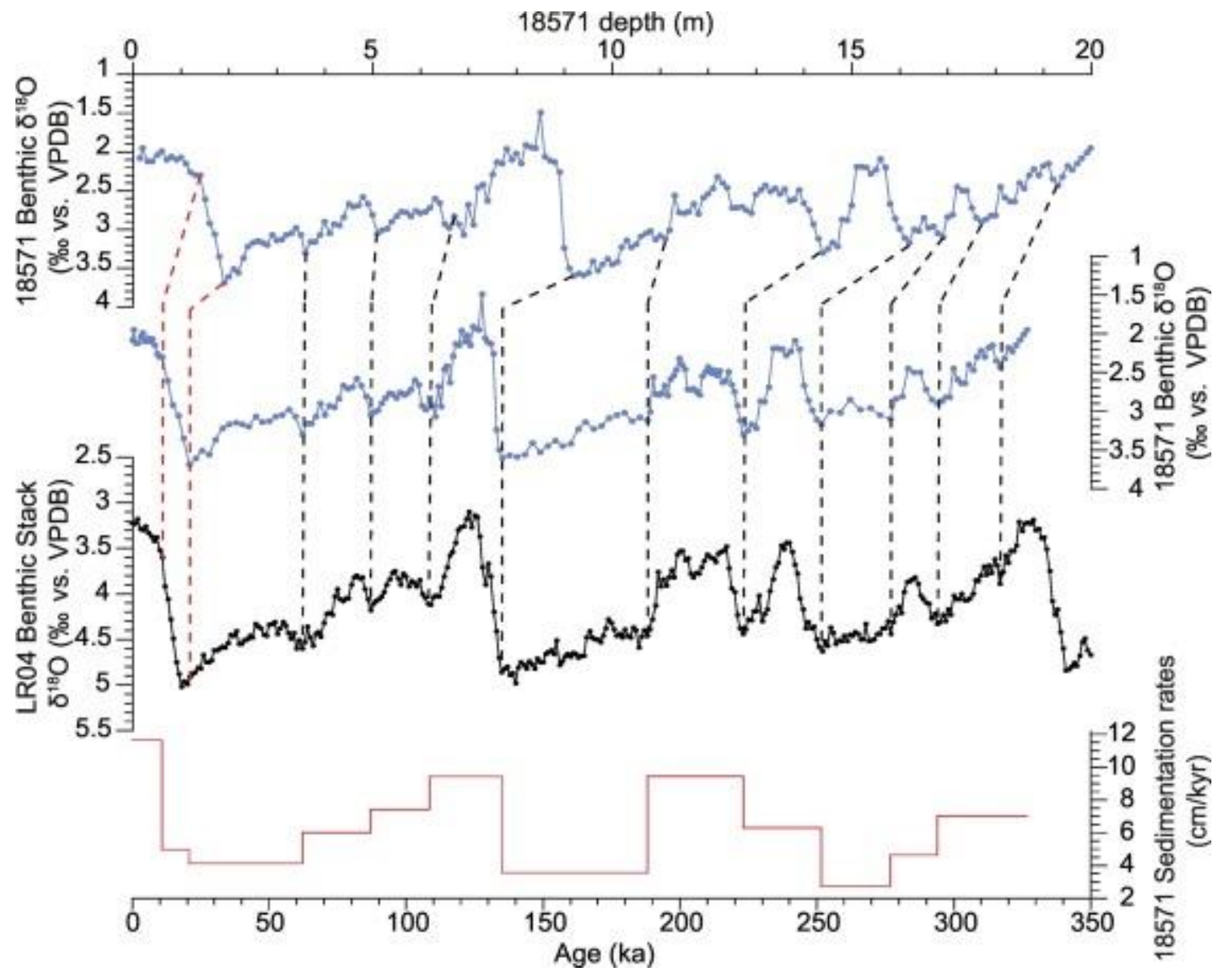


Figure 5
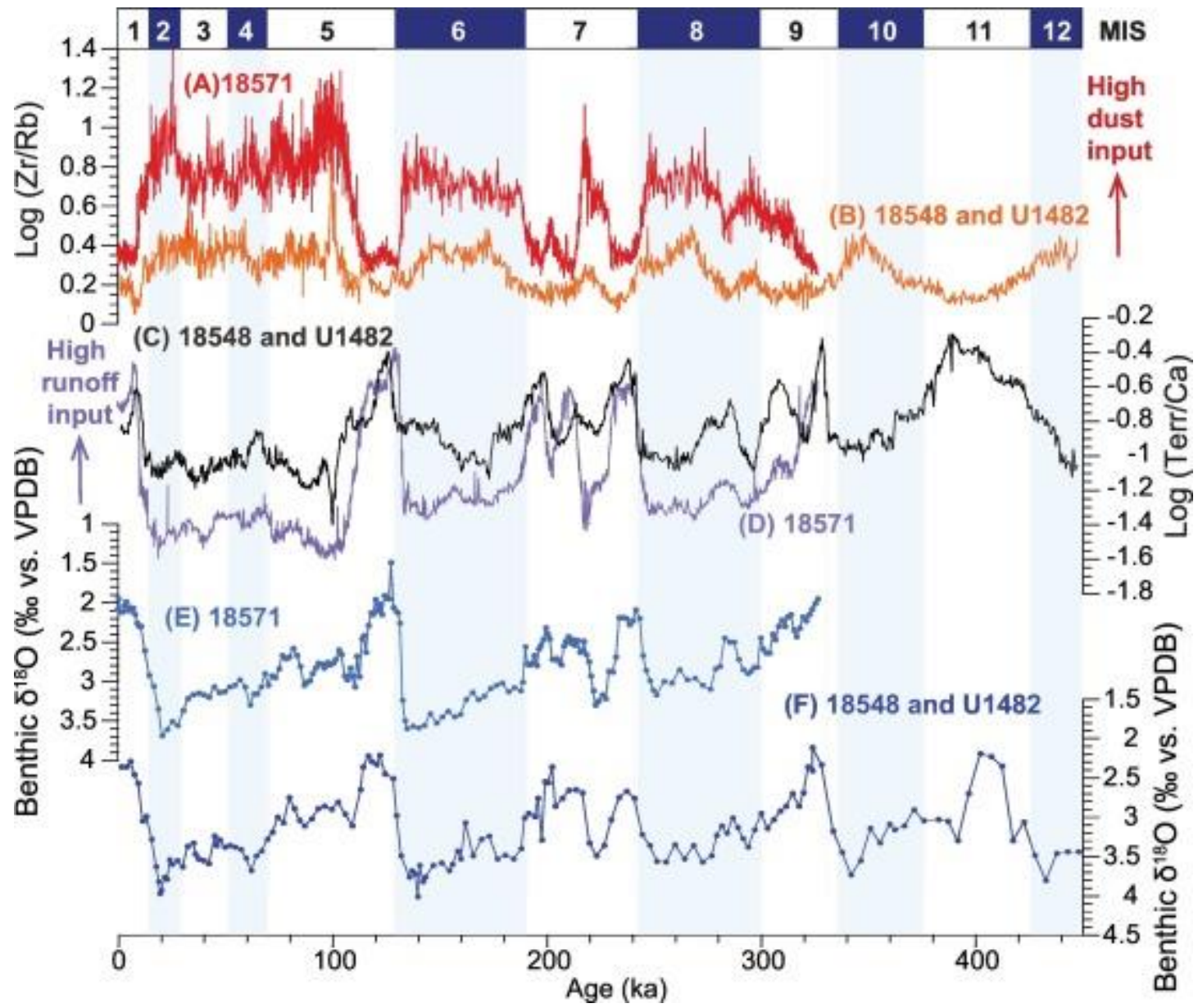
Figure 6

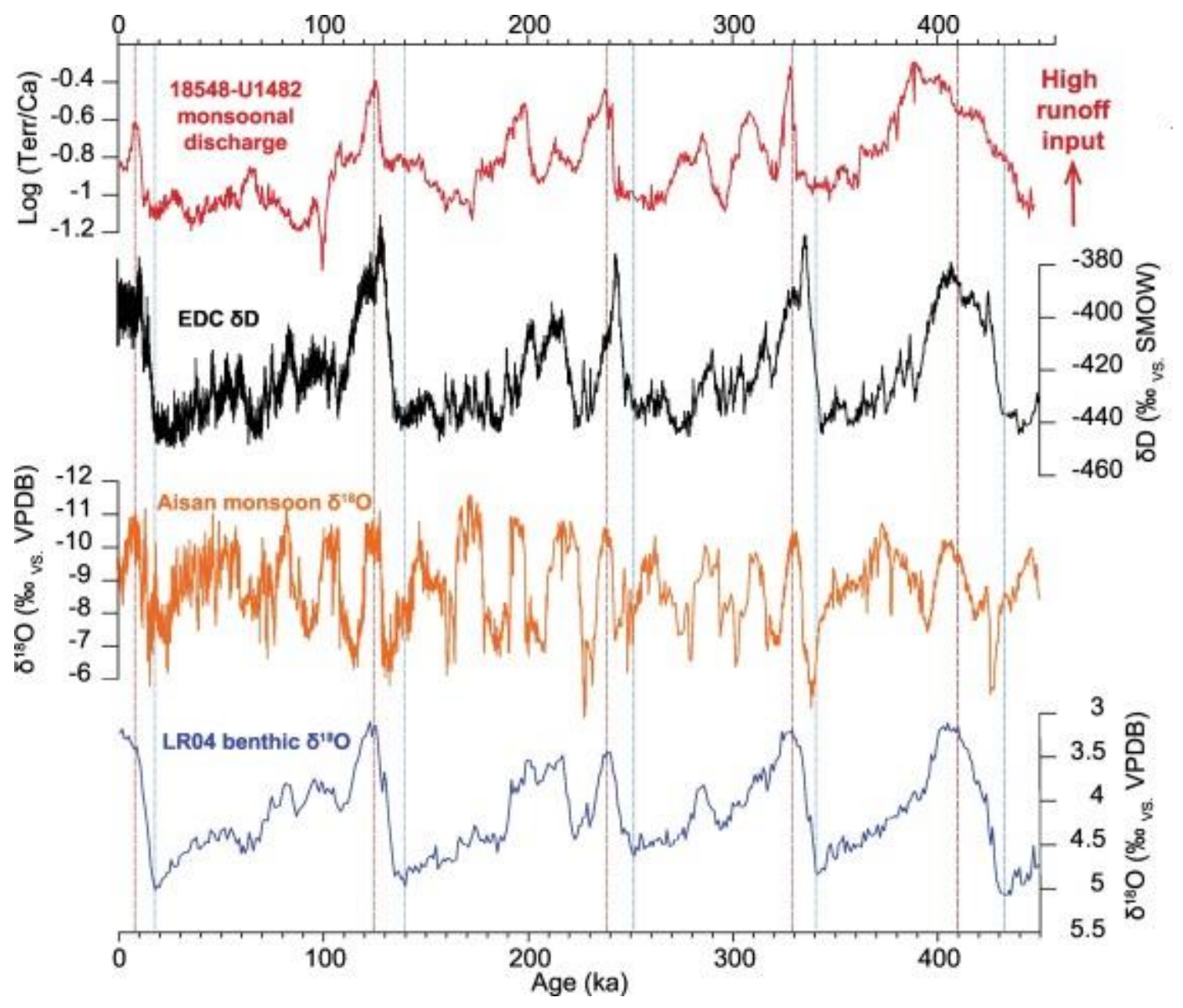


Figure 7

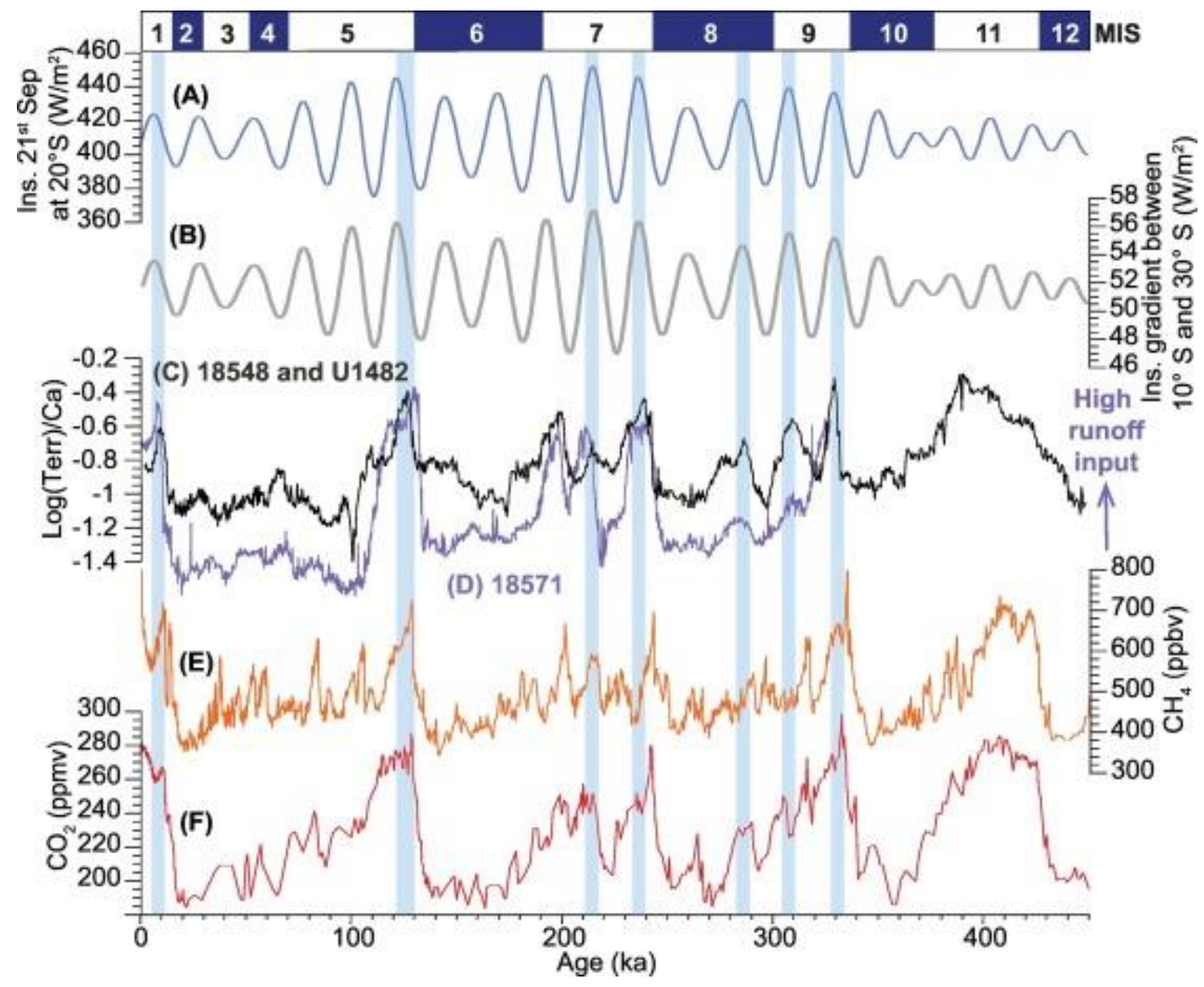

